\title{
Condicionantes Sociais e Econômicos do Acesso à Universidade
}

\author{
Fernando Borges Moreira Monteiro*
}

\section{INTRODUÇÃO}

O acesso à Universidade tem sido nas últimas décadas um dos momentos de maior perplexidade dos estudantes brasileiros que buscam uma formação de nfvel superior.

Este momento crítico e incvitável de todo o alunado que busca galgar os degraus da Universidade, que tcm sido vivenciado com emoção e desespero pelos familiares dos candidatos, recebe influências as mais diversas, que, de um modo ou de outro, podem ser decisivas no sucesso do ideal desejado.

No entanto, estas influências năo säo percebidas no momento específico em que os exames sảo prestados, mas sāo o reflexo de uma série de condicionantes que atuam ao longo da formaçảo básica e secundária do pretendente e que têm uma estreita relação com suas origens sócio-econômicas.

O presente trabalho tem por objetivo, além de aplicar aspectos doutrinários e desenvolver a técnica de pesquisa de assunto de relevante interesse conjuntural, analisar esses condicionantes de origem sócio-cconômica, e verificar como eles interferem no acesso à Universidade brạsileira.

O tema representa um dos grandes desalios da educaçāo superior do Paf́s pelo reflexo que poderá ter na formaçäo das clites nacionais, no desenvolvimento científico e tecnológico, na qualificaçāo de pessoal para o mercado de trabalho e, especialmente, na democratizaçāo da Universidade.

A idéia central é examinar a problemática do acesso à Universidade pela análise dos relatorios dos concursos vestibulares de algumas Instituiçöes brasileiras e verificar como estes condicionantes apresentam-se nas diversas regiōes do País.

Evidentemente nâo tem sentido analisar o processo seletivo do vestibular sem considerar a educação brasilcira como um todo, já que as origens do problema se situam

- Professor da UNIVIRSIDADE DB FORTALEZA (UNIFOR). Presidente da Comissilo de Coordenaçăo do Concurso Vestibular da UNIIFOR. 
em todos os niveis de formação e guardam uma estreita relaçăo com a estrutura politica, econômica e social existente no País.

Na realidade a seleção dos que teräo ingresso na Universidade começa muito longe dela e tem infcio na escola primária, onde, de cada 100 alunos matriculados, apenas 15 concluem o primeiro grau e somente 10 conseguem chegar ao término do $2^{\circ} \mathrm{grau}$. Dos que terminam o curso secundário, entre 5 e 6; no Nordeste, este número cai para 4, que têm condiçōes de candidatar-se ao vestibular, uma vez que os demais, por motivos vários, necessitam ingressar no mercado de trabalho siem a formaçäo superior.

Mesmo assim, o contigente de candidatos que procura entrada na Universidade apresenta uma grande heterogeneidade na sua origem social que, no entanto, já difere bastante do perfíl médio da populaçăo brasileira como um todo.

As portas da Universidade, no momento da escolha do curso a seguir, manifesta-se um outro forte processo seletivo: os candidatos oriundos das camadas de baixa renda optam por carreiras de baixo prestígio social, como Letras, Pedagogia, Ciências Sociais, Arquivologia, Biblioteconomia ctc, enquanto aqueles originados das classés de média e alta renda preferem as chamadas profissöes liberais, tais como Mcdicina, Engenharia, Direito etc.

Damasceno (1986) reafirma esta idéia quando diz:

"Estudos empiricos expressam de forma categórica que os estratos sociais mais altos ocupam os cursos considerados de alto prestfgio.

Tais cursos preparam de modo mais direto para o exerctcio das atividades relacionadas com o controle nos diversos niveis; legitima-se, assim, através do diploma de doutor, as funçōes sociais hierarquizadas, de acordo com o esquema das classes sociais.

Fecha-se, assim, o círculo vicioso: os mais ricos väo para os cursos que proporcionam maiores ganhos, o que thes possibilitará, pelo menos, conservar o status das famtlias de origem, e os mais pobres terminam nos cursos que näo lhes abrem muitas perspectivas, tanto em termos de rendimentos, como de lugar no mercado de trabalho.

Em suma, o processo seletivo a que o candidato ao ensino superior é submetido tem como critério decisivo a sittuação econômica das familtias."

Esta auto-exclusảo do processo seletivo, embora nāo tenha uma explicaçáo sociologica convincente, certamente tem muito a ver com a plena consciência do indivíduo de que seu nfvel de conhecimento não the permite aspirar carreiras de elevado prestigio, conformando-se, entāo, com pretensōes mais modestas.

Costa Ribeiro (1986), comentando o assunto, diz:

"Embora a escolha seja feita pelo individuo, ela representa apenas o fittro de um quàdro de referência sócio-econômica e cultural historicamente determinado.

A cada carreira estäo associados candidatos com perfis sócio-econômicos extremamente definidos. Forma-se assim uma escala de prestigio social das carreiras, com implicaçōes axtremamente importantes para a compreensalo da estrutura polftico-social do pats."

Após a aplicaçảo das provas do exame vestibular, que deve selecionar os que apresentam um melhor desempenho, verifica-se que o que houve na verdade foi a exclusăo dos mais pobres, uma vez que nesta faixa de renda concentram-se os candidatos menos preparados. 
A análise dos relatórios sócio-cconômicos dos candidatos inscritos $\mathrm{em}$ várias universidades brasileiras mostra, quando comparada com o perfil dos aprovados nestas instituiçōes, que existe uma indiscutível influência das condiģôes de renda das famflias nesta scleçăo.

Estes aspectos estăo amplamente mostrados ao longo deste trabalho, onde săo verificados alguns condicionantes, especialmente de origem social e econômica, que influem neste tipo de seleçäo.

$\mathrm{Na}$ realidade, a grande seletividade social e econômica, ocorrida nos concursos vestibulares do pais, reflete de uma maneira clara as amplas desigualdades existentes na sociedade brasileira.

Querer culpar os candidatos pelo scu despreparo, para enfrentar os exames, ou penalizar o ensino por eles recebido nos graus anteriores, parece-nos uma visåo distorcida do problema, que como vimos tem rafzes bem mais profundas e situadas num contexto sócio-econômico muito maior.

Outra grave disfunção operada durante o processo de seleção para o acesso à Universidade é observada, quando verificamos que candidatos se matriculam nas instituiçōes públicas e quais aqueles que se dirigem para os estabelecimentos privados.

Giannotti (1987) comenta muito bem quando expressa a opiniấo de que:

"Nas condiçöes atuais, grande parte dos estudantes mais preparados, aqueles que têm o sucesso quase garantido nos exames vestibulares, provêm de escolas privadas e muito bem pagas. É natural que a burnguesia poupe seus filhos do vexame que se tomou a escola pública.

Logo depois de saltar a barreira dos vestibulares, o aluno, que pagou a escola a vida inteira, cursa gratuitamente sua faculdade.

Resulta disso que as melhores universidades do pats salo frequentadas pelas melhores familias, brancas, refinadas, enquanto a pequena burguesia mais pobre e as classes trabaUhadoras ou fazem esforços gigantescos para romper essa barreira, ou tratam de colocar seus fillos em escolas de segunda categoria."

Como cerca de $60 \%$ das vagas anualmente oferecidas para ingresso na Universidade situam-se em Instituiçôes privadas, especialmente em estabelecimentos isolados, pode-se têr uma idéia das proporçöes da discriminação ocorrida.

Recentemente, a partir de 1988, com a tendência de cada Universidade tratar do seu próprio processo seletivo de acesso e com a adoção de níveis mínimos de desempenho no concurso, criou-se mais uma barreira para a entrada das classes menos favorecidas: a chamada vaga ociosa.

O não preenchimento de vagas oferecidas pelo năo atingimento de nfveis mínimos vem penalizando, principalmente, os pretendentes as instituiçōes públicas e acontece especialmente nos cursos de baixo prestf́gio, como as licenciaturas, e traz de volta ao cenário universitário problemas que remontam a década de 50/60.

Dentro deste contexto ocorre-nos lembrar uma indagação de Costa Ribeiro (1988), quando comenta que as Universidades públicas têm um discurso democratizante e uma prática elitizante:

"Para quê aumentar o número de vagas para depois deixa-las ociosas?

Como ter argumentos para manter a gratuidade da Universidade Pública se uma politica deliberada impede o acesso dos menos favorecidos? 
Como usar o argumento da pressäo sobre a escola de $2^{a}$ grau para justificar esta poltitica de acesso, se é barrada a entrada daqueles que teriam a passibilidade de, frequientando uma Universidade Páblica, se tomarem melhores docentes dos graus anteriores de ensino e assim melhord-los?

Como conciliar o discurso da democratização do Pals e da Universidade com a postura de manutençäo e aumento dos privillégios da classe alta que habita hoje, mais do que ontem, a classe discente das Universidades Públicas?

Como defender a gratuidade do ensino para um gnupo cada vez mais privilegiado, com refeiçōes ao preço de US\$ 0,00012, num pats de subnutridos?

Será que há esperança de um dia a Universidade Pablica Gratuita e Autonôma tomar consciência de suas reais responsabilidades sociais, num pais como o nosso, descer da torre de marfim em que se encontra e mitigar as lutas da miséria?

Esperamos que sim."

E nós também!

\section{ANTECEDENTES HISTÓRICOS}

O Brasil năo contava com nenhuma escola de nfvel superior até 1808 , quando para aqui veio a Famflia Real Portuguesa. Esta ausência de escolas de nfvel superior era decorrente, evidentemente, do obscurantismo do processo de colonizaçảo portuguesa, que defrontando-se com nativos em estágios primitivos mantinha no poder uma classe dominante rica e de pouca cultura. Casos isolados de famflias que se interessavam pela cultura europeia eram resolvidos enviando seus filhos para estudar na Metropole.

As primeiras escolas superiores brasilciras surgiram depois do estabelecimento de D. Joáo VI no Brasil e objetivaram unicamente manter a dominaçäo das classes dirigentes através dos seus interesses burocráticos e polfticos. Estas escolas eram uma imitaçăo das instituiçöes portuguesas, já na época defasadas das congêneres na Europa, e seguiam modelos medievais, preparando os filhos da classe dominante para o exercício das profissöes liberais de prestf́gio, como Direito, Medicina e Engenharia.

Com a independência, as escolas superiores expandiram-se, mas mantendo sua dependência econômica e cultural de Portugal e serviam para a formação dos quadros administrativos do Império, especialmente nas Faculdades de Direito.

A República também nã̉o trouxe substanciais alteraçōes no contexto da insipiente educaçăo superior do Paf́s da época, que permaneceu como sendo destinada às elites dirigentes $\mathrm{c}$ às famflias de maiores posses.

Em relaçäo ao acesso dos estudantes às Instituiçöes de Ensino Superior, podemos estabelecer as seguintes fases:

\subsection{O período até 1911}

O ingresso no ensino superior no Brasil, até 1911, era feito através de exames de madureza preparatórios, que se constituíam em exames de sáda do curso secundário $\mathrm{e}$ não entrada no ensino superior. 
O ensino secundário, naquela época, cuja duraçăo oscilou de sete a cinco anos no perfodo, era feito exclusivamente para obter matrícula nos cursos superiores e cra tido pelos crfticos da época como irracional e grosseiramente organizado. Exceçäo feita ao Colégio Pedro II, freqüentado por uns poucos privilegiados, o ensino secundário, desde o Império, sempre esteve sob forte suspeiçäo.

Os alunos frequientavam os cursos preparatórios que os remetiam a provas perante "mesas de exame", organizadas nas escolas superiores e nos liceus equiparados ou no Colégio Pedro II, quando no Rio de Janeiro.

Em 1875, a rede de estabclecimento de ensino superior brasileira näo ia além de seis escolas isoladas.

\subsection{A reforma Rlvadávia Correa}

O exame de admissāo às escolas brasileiras de ensino superior foi introduzido pelo Decreto $\mathrm{N}^{\circ}$ 8.6569, de 05.04.1911, no Governo Hermes da Fonseca, sendo Ministro da Justiça e Negócios Interiores Rivadávia da Cunha Correa e constava, no dizer da época, de "prova escrita em vernáculo, que revela a cultura mental que se quer verificar, e de uma prova oral sobre línguas e ciências".

Embora introduzidas algumas inovaçōes, como ensino livre, a supressäo de dipplomas e certificados e a desoficializaçäo do ensino, a rcforma manteve exames preparatórios, até mesmo em colégios particulares, perante bancas examinadoras, agora indicadas pelo Conselho Superior de Ensino. Na realidade estas avaliaçöes eram um Exame de Estado, aferidor do ensino secundário ministrado na época.

Em 1920, foi criada oficialmente a primeira universidade brasileira, no Rio de Janeiro, época em que predominavam e eram apreciadas as qualidades de homem culto. As profissōes liberais nessa época eram restritas às de Advogado, Médico c Engenheiro.

\subsection{A reforma Francisco Campos}

O fim dos exames preparatórios e dos exames parcelados ocorreu durante o Governo Provisório de Getálio Dorneles Vargas, sendo Ministro da Educaçāo e Saúde Francisco Campos, pelo Decreto $N^{\mathbb{R}} 19.890$, de 18.04.31, que modificou o ensino secundário, relevando o seu caráter educativo, em detrimento do enfoque de mero instrumento de acesso ao ensino superior.

Por este documento legal o ensino secundário passou a ser ministrado em etapas: uma, comum e fundamental, com 5 anos, e outra complementar, de 2 anos, destinada a uma adaptação dos estudantes às futuras especializaçöes, subdividindo-se em pré-jurfdico, pré-médico, pré-politécnico.

Assim, houve uma inversảo de perspectiva, uma vez que o antigo exame de salda passou a configurar-se como um exame de ingresso, onde verificava-se a capacidade do candidato de seguir determinado curso superior.

Com isto, os concursos vestibulares passaram a ser moldados dentro de uma correspondência faculdade-curso e objctivavam, unidirecionalmente, a selecionar candidatos para cada curso especffico. 
A partir da reforma Francisco Campos somente poderia submeter-se aos exames vestibulares o candidato que houvesse cursado regularmente os sete anos de estudos seriados e prestado exames em cada uma das séries, perante bancas examinadoras, supervisionadas pelo Fiscal da Uniảo. existentes.

Nesta fase, havia tantos vestibulares na Universidade quantos fossem os cursos nela

Em 1930 possufa o Brasil apenas 2 Universidades, passando este número para $5 \mathrm{em}$ 1940, pra 12 em 1950 e para 19 em 1955.

A evolução do alunado nas universidades brasilciras no período 1940/1961 apresentou a seguinte variação:

TABELA 1

\begin{tabular}{c|r|c|c}
\hline Ano & Vagas & Matrículas & Conclusões \\
\hline & & & \\
1940 & 9.200 & 27.671 & 6.504 \\
1950 & 14.600 & 48.999 & 8.303 \\
1960 & 39.780 & 93.202 & 16.893 \\
1961 & 43.240 & 98.892 & 18.226 \\
\hline
\end{tabular}

\subsection{A lel de Diretrizes e Bases}

A lei Ne 4.024/61, que redefiniu o primeiro e o segundo ciclos do ensino secundário e os cursos técnicos, praticamente nấo deu nenhuma atençăo ao exame vestibular para ingresso na Universidade.

A lei de Diretrizes a Bases, como passou a ser conhecida a Lei $N^{2} 4.024 / 61$, deu a plena equivalência a todos os cursos de grau médio para efeito de ingresso nos cursos superiores. Isto fez com que houvesse um crescimento na demanda de vagas à Uniyersidade, na medida em que tornou possfvel ao concludente de curso técnico candidatar-se aos concursos vestibulares de qualquer curso superior.

Assim, o acesso à Universidade passou a constituir-se em verdadeiro concurso de habilitaçăo, caracterizado realmente como um exame de entrada e, de uma maneira geral, dirigido especilicamente para o curso a que se destinava.

Por outro lado, na década de 60 , ocorreu um aumento na demanda ao ensino superior, provocado pelo rápido processo de crescimento industrial e pela maior urbanização ocorrida no pafs, como também pelo aumento das vagas nos ginásios e colégios públicos, e pelas próprias transformaçöes sociais e econômicas verificados neste perfodo.

Nessa época, a habilitaçấo a um curso superior assentava-se em um desempenho mínimo nos exames vestibulares, que, se nåo atingido, criava muitas vagas nos cursos de menor prestígio ou, se atingido por um número muito grande de candidatos, nos cursos de grande prestígio, criava a figura do "excedente".

A questäo dos "excedentes" gerou uma grande insatisfação na classe média, ocupando um lugar de destaque no centro das discussōes da época e provocando grandes mobilizaçőes por mais vagas e mais verbas para as universidades. 
No perfodo 1964-1968, o número de candidatos ao ingresso na Universidade cresceu cerca de $120 \%$, contra uma elevação de vagas de $50 \%$. Em 1968, o número de excedentes nos diversos vestibulares do país era na ordem de 125.000 , mostrando cruamente a grande defasagem entre a demanda $\mathrm{e}$ a oferta de vagas.

Para contornar estes problemas advindos da figura do excedente, a grande maioria das Universidades passou a exigir cada vez mais conhecimentos especfficos em seus exames, chegando, em alguns casos, à grave distorçāo de incluir em suas provas conteúdos de cursos de ensino superior.

A escola secundária, nảo tendo condiçöes de ministrar conhecimentos acima do seu nível, possibilitou a criaçăo de entidades à margem do sistema legal de ensino, conhecidas como "cursinhos", que também preparavam candidatos para a acirrada disputa pela vagas existentes na Universidade.

Nessa fase, ogrande número de candidatos a selecionar indicou o empregode formas mais rápidas de avaliaçăo, como os testes de múltipla escolha e a utilização de equipamentos eletrônicos de rápido e seguro processamento dos dados referentes ao concurso.

\subsection{A reforma universitária}

A Lei $N^{0} 5.540 / 68$, que estabeleccu a chamada rcforma universitária, representon, na verdade, um elenco de medidas determinadas pelo Governo, com o objetivo de eliminar as tensōes sociais e os distúrbios provocados pela defasagem demanda/oferta de vagas no ensino superior.

A reforma universitária, dentre as muitas modificaçōes que introduziu no ensino superior do pafs, como o sistema de créditos, a departamentalizaçảo dos docentes e disciplinas, o ciclo geral, estabeleceu a retomada do caráter de exame de saf́da para o concurso vestibular, tornando-o, além do mais, exclusivamente classificatorio, em vez de habilitatório como até entảo.

Alem da reforma outras medidas foram adotadas pelo Governo Federal, com o objetivo de aumentar as vagas para o acesso à Universidade. Escudado pelo Ato Institucional $\mathrm{n}^{9} 5$, estabeleceu pelo Decreto № 405/68, a irredutibilidade de vagas pelas Instituiçốes de Ensino Superior em qualquer ano letivo, como também obrigou a realizaçäo de novo concurso vestibular até o preenchimento total das vagas anunciadas.

Paralclamente a estas medixlas internas de expansão do ensino superior, o Governo propôs também um auxílio financeiro suplementar para as Instituiçöes que aumentassem a sua oferta de vagas e também orientou o Conselho Federal de Educaçāo, no sentido de um afrouxamento nos critérios de autorizaçăo e reconhecimento de novos cursos, especialmente $\mathrm{cm}$ relação às escolas particulares.

Com a expansáo das vagas no ensino supcrior na década de 70 , que foi divulgada no discurso oficial como sendo um processo democratizante fruto do milagre brasileiro, inverteu-se a dependência administrativa das I..stituiçōes de Ensino, passando à iniciativa privada boa parte do processo educacional supcrior, salientando-se que este crescimento foi promovido fundamentalmente em estabelecimento isolados.

A expansảo das vagas no $3^{\circ}$ grau, para atender às pressōes sociais e politicas da classe média, que via na cducação a única forma de ascensảo social, também teve um objetivo econômico, o de modernizar o ensino superior do país para adequá-lo às necessidades de seu crescimento acelerado, gerando graduados para cargos na burocracia pública e privada. 
É neste contexto expansionista que surgem os concursos vestibulares unificados, como uma soluçăo econộmica para avaliar grandes massas de candidatos a uma vaga no ensino superior.

O vestibular unificado permitia que o aluno disputasse uma vaga $\mathrm{em}$ várias instituiçöes ao mesmo tempo, possibilitando o cumprimento da filosofia do pleno preenchimento das vagas, evitando-se, em conseqüencia, multiplicidade de matrícula.

\subsection{A volta das habilidades especificas}

O otimismo expansionista da reforma universitária cómeçou a apresentar seus primeiros sintomas de crise quando o milagre do desenvolvimento dava sinais de falência, com reflexos no mercado de trabalho. Inicia-se nos primeiros anos da década de 80 a reduģăo das vagas do ensino superior, com a consequéente retraçäo do poder público de sua responsabilidade econômica pelo ensino de $3^{2}$ grau.

Datam desta época a tentativa de privatizaçấo do ensino superior, a diminuiçăo de recursos para a educaçăo e a busca de um novo regime para as universidades públicas, o que tornava necessário procurar uma redefiniçăo do papel do Estado na política educacional do Pafs.

O Decreto $\mathrm{N}^{2} 79.298$, de 24.03.77, deu maior liberdade as Instituiçōes de Ensino Superior para organizar seu sistema de concursos vestibulares, uma vez que estabelecia que clas poderiam utilizar critérios, métodos e procedimentos proprios nestes exames de seleçäo.

A partir daf foram introduzidas modificaçöes no vestibular que levaram ao aparecimento de novos modelos de exame, de uma maneira geral, contrários à unificaçăo do concurso, procurando atender mais os interesses da própria Instituição.

Atualmente vem tendo grande aceitação o modelo de vestibular em duas fases, que eliminando grande parte dos candidatos na $1^{\mathrm{A}} \mathrm{etapa}$, procura dar uma solução operacional para o elevado número de candidatos inscritos e, também, introduz, de volta, os exames discursivos na $2^{\circ}$ etapa, buscando uma certa especificidade de áreas de conhecimento.

Controvérsias à parte, em relaçăo à validade do novo processo de avaliaçăo, que por certo selecionará provavelmente os mesmos candidatos se tivesse sido utilizado o modelo anterior, pode-se esperar uma substancial alteraçäo na conduçáo do ensino do $z^{2}$ grau, já que é imediato o reflexo naquele nível de ensino.

Por outro lado, a introduçāo de provas específicas para diversas opçōes de carreiras, por certo trará, como corolário inevitável uma perda de globalidade do ensino de $2^{2}$ grau, um consequaente retorno a um passado de 40 anos.

O momento deve ser o de repensar o acesso à Universidade brasileira, especialmente tendo em vista a inclusăo de variáveis que escapam ao sistema educacional e que têm localização em alguns condicionantes sociais e econômicos que influem nesta seleçăo.

\section{O ACESSO AO ENSINO SUPERIOR}

A entrada de alunos na Universidade brasileira de hoje é extremamente seletiva, com condicionantes de toda ordem, mas sempre tendo, como vetor ponderável, o fator econômico. 
As universidades públicas e gratuitas selecionam sempre os candidatos oriundos das camadas economicamente favorecidas, que frequientaram escolas particulares de elevado custo, restando aos demais as instituiçőes de ensino superior privadas, onde o ensino é pago e a grande maioria das vezes de qualidade inferior.

O problema do acesso ao $3^{\circ}$ grau transcende os limites da universidade e $\mathrm{c}$ resultante, em grande parte, de condiçöes que impossibilitam o seu equacionamento politico e social.

$\mathrm{Na}$ realidade a democratização do acesso ao ensino superior tem origem na possibilidade de superação das condiçōes de ingresso no primeiro e segundo graus, para os quais, basicamente, se pretende uma efetiva melhoria através do estabelecimento de um amparo ao estudante carente e de uma melhor qualificaçấo do seu corpo docente.

Entendemos ser um grave erro procurar uma expansão da entrada do ensino de $3^{\circ}$ grau pelo crescimento indiscriminado de vagas ou pelo rebaixamento dos níveis de conhecimentos exigidos.

\subsection{O problema educacional brasileiro}

É muito complexo o problema educacional do país, onde, além dos seus múltiplos aspectos, não há a menor articulação cntre suas partes.

O conhecimento e a discussāo da etapa dos diversos segmentos da educação, cada um deles com suas peculiaridades próprias, passa sem dúvida por algumas consideraçōes sobre a história recente do pals.

A polftica educacional dos governos militares produziu uma reduçẩo dos recursos disponíveis, uma crescente privatizaçăo do ensino, uma degradaçăo no salário dos professores c uma deterioração nas condiçōes de trabalho nas escolas.

A crise do ensino brasileiro, ampliada a partir do regime autoritário, apresenta no momento um quadro critico que está a exigir da naçāo soluçöes urgentes, especialmente agora quando a sociedade, ao cscolher seus dirigentes, pode discutir e discernir melhor os seus problemas.

A cducaçảo no paf́s näo pode ser equacionada isoladamente $\mathrm{em}$ cada um dos seus aspectos, uma vez que eles sāo interdependentes, mas através da definiçäo de políticas claras para todo o complexo educacional, junto de uma ampla discussão da sociedade e de seus diversos sctores.

Torna-se necessário aplicar no pafs uma polftica de universalização do ensino fundamental, com o objetivo de erradicar o analfabetismo e de oferecer a todos uma escolaridade mínima. Para tanto é indispensável superar os déficits quantitativos ainda existentes como também promover uma melhoria qualitativa no proprio ensino, de modo a minimizar a repetência e a evasāo durante os oito anos do $1^{\circ} \mathrm{grau}$.

Ao mesmo tempoe preciso ampliar o prosseguimento dos estudos de $2^{a}$ grau e rever a sua participaçảo na estrutura de ensino. Este nivel de educaçẩo vem apresentando um crescimento em taxas menores do que o número de egressos da escola fundamental, o que indica a necessidade de uma ampliação nas oportunidades de acesso atualmente oferecidas.

Tambem uma redefiniçâo da identidade do $2^{2}$ grau de ensino torna-se imperiosa, uma vez que o mesmo perdeu sua caracteristica de formaçäo geral e năo vem correspondendo as reais necessidades do mercado de trabalho. 
Porém, a simples garantia de recursos para a expansäo e melhoria do ensino de $1^{\circ}$ e $2^{\circledR}$ graus não promoverá a solução dos percalços atuais, se medidas complementares de apoio nāo forem adotadas, especialmente $\mathrm{cm}$ relaçäo às camadas de baixa renda, onde estâo localizados os maiores índices de cvasão $\mathrm{c}$ repetência e em relaçảo à valorização profissional do docente, responsável maior pela boa qualidade do ensino.

No ensino superior a crise também tem uma magnitude e uma gravidade que estäo a exigir do Governo Federal soluçōes imediatas, pois estas dificuldades teräo repercussäo na preparaçäo das elites brasilciras que enfrentaräo os desafios das próximas décadas.

Dentro da problemática do ensino superior destaca-se a discriminação social no acesso às universidades, onde condicionantes vêm atuando cada vez mais de modo a selecionar candidatos, cuja origem situa-se nas faixas de mais alta renda para as universidades públicas e gratuitas, em detrimento dos candidatos que vêm de famflias de renda modesta, que somente encontram vagas em instituiģões particulares e pagas.

\subsection{O ensino superior no Brasil}

O ensino de $3^{\circ}$ grau no país.vem sendo ministrado em Universidades, em Federaçöes de Escolas e Faculdades Integradas e em Estabelecimentos Isolados, que podem ter uma dependência administrativa pública ou privada, sendo as primeiras de natureza federal, estadual e municipal.

Segundo a publicaçâo do MEC "Sinopse de Ensino Superior-Graduaçäo", estava o paí, em 1987, com 853 Instituiçōes de Ensino Superior, das quais 54 eram federais, 83 estaduais, 103 municipais e 613 particulares.

Em 1875 contava o Brasil com seis Escolas Isoladas de Ensino Superior e somente em 1920 foi criada sua primeira Universidade. Em 1930 o pafs tinha duas Universidades, em 1940 cinco, em 1950 doze e em 1955 dezenove.

No quadro $n^{2} 1$ observa-se a evoluçăo đo número de IES no país, a partir de 1970.

QUADRO №1

EVOLUÇĀO DO NÚMERO DE INSTTTUIÇỐES DE ENSINO SUPERIOR NO PAÍS, SEGUNDO A NATUREZA.

\begin{tabular}{c|c|c|c|c|c}
\hline \multirow{2}{*}{ ANO } & \multicolumn{2}{|c|}{ Univensidades } & \multicolumn{2}{c|}{$\begin{array}{c}\text { Federaços de Escola e } \\
\text { Estabelecimentos Isolados }\end{array}$} & \multirow{2}{*}{ TOTAL } \\
\cline { 2 - 5 } & Número & $\%$ & Número & $\%$ & \\
\hline 1970 & 50 & 9,69 & 466 & 90,31 & \multirow{2}{*}{516} \\
1975 & 59 & 6,73 & 818 & 93,27 & 877 \\
1980 & 65 & 7,43 & 810 & 82,57 & 875 \\
1985 & 68 & 7,92 & 791 & 92,08 & 859 \\
1986 & 78 & 9,05 & 784 & 90,95 & 862 \\
1987 & 82 & 9,61 & 71 & 90,39 & 853 \\
\hline
\end{tabular}

Fonte: SEEC-MEC 
Observa-se um crescimento de $70 \%$ no número de instituiçöes no perfodo 1970 1975 e a partir daf uma diminuiçăo pequena, porém constante. Tal fato pode ser explicado pela transformação de Federações em Universidades ou de grupos de Escolas Isoladas em Universidades, o que 6 confirmado pelo aumento destas f́ltimas, durante todo o perfodo $70 / 87$.

Destaque-se, também, que somente cerca de $10 \%$ das instituiçōes de ensino do pafs sảo Universidades, enquanto os $90 \%$ restantes sấ Estabelecimentos Isolados ou Federaçōes do Escolas.

Em relaçăo à dependência administrativa das Instituiçōes de Ensino Superior, temos o quadro $n^{2} 2$ abaixo:

\section{QUADRO № 2}

EVOLUÇĀO DO NÚMERO DE INSTITUIÇŌES DE ENSINO SUPERIOR NO PAIS, SEGUNDO A DEPENDÊNCIA ADMINISTRATTVA.

\begin{tabular}{c|c|c|c|c|c}
\hline \multirow{2}{*}{ ANO } & \multicolumn{2}{|c|}{ Públicas } & \multicolumn{2}{c|}{ Particulares } & \multirow{2}{*}{ TOTAL } \\
\cline { 2 - 5 } & Número & $\%$ & Número & $\%$ & \\
\hline 1970 & 159 & 30,81 & 357 & 69,19 & 516 \\
1975 & 239 & 27,25 & 638 & 72,75 & 877 \\
1980 & 228 & 26,06 & 647 & 73,94 & 875 \\
1985 & 233 & 27,12 & 626 & 72,88 & 859 \\
1986 & 241 & 27,96 & 621 & 72,04 & 962 \\
1987 & 240 & 28,14 & 613 & 71,86 & 853 \\
\hline
\end{tabular}

Fonte: SEIEC-MEC

Verifica-se que das 853 Instituiçōes de Ensino Superior funcionando no pafs em 1987, 240 têm uma dependência administrativa do Poder Público, enquanto 613 săo entidades privadas.

A forte predominância das instituiçóes particulares, com quase $72 \%$ do total, mostra claramente a transferência de responsabilidades do poder público em relaçăo ao ensino superior, como tambêm um efetivo ônus para aqueles que aspiram a uma formaçăo universitária, que por certo terão cada vez maiores dificuldades de acesso a um ensino gratuito e de boa qualidade.

Tal fato, no entanto, não tem sido o maior entrave no ensino superior brasileiro, uma vez que existem instituiçōes públicas de alto nível, como também entidades privadas que ministram cursos da melhor qualidade.

A grande questäo da universidade brasilcira sem dávida passa por seu desajustamento da realidade do país, o que se manifesta pela formaçäo de profissionais inadequados às solicitaçöes do mercado de trabalho, por uma pesquisa desvinculada dos interesses nacionais imediatos e pelo alheamento das comunidades às quais deveria servir.

Esta dicotomia entre o "ser" 00 "dever ser" do ensino superior brasileiro tem origem na Reforma Universitária, de 1968 , que estabelecia que os cursos de $3^{\circ}$ grau do Pafs seriam sempre feitos em Universidades, de estrutura assemelhadas, excrcitando de forma conjunta o ensino, a pesquisa e a extensão. 
Na realidade constata-se que a maior parte do ensino superior do pafs é lecionado em estabelecimentos isolados e em escolas particulares. Vimos nos quadros $\mathrm{n}^{2} 1 \mathrm{e} \mathrm{n}^{2} 2$ que as universidades constituem-se em cerca de $10 \%$ das instituiçōes de ensino superior e que $72 \%$ delas têm uma dependência administrativa de empresas privadas.

Modernamente o próprio Ministério de Educação reconhece a impropriedade de um tratamento uniforme para as diversas instituiçöes de ensino do pafs e para as várias regiöes $\mathrm{cm}$ que elas estäo sediadas.

Deseja-se na atualidade para as Instituiçōes de Ensino Superior muito mais uma forma de compromisso com a qualidade do ensino por ela ministrado, seguindo cada uma delas seus próprios objetivos e vocaçöes, adotados de acordo com os interesses da regiảo em que estăo localizadas e segundo formas que thes pareçam mais adequadas.

Entende Paulo Renato Souza, da Universidade Estadual de Campinas, que a "Universidade, como uma instituiçäo sui-generis dentro do sistema de ensino superior, deveria contemplar pelo menos três qualidades essenciais:

a) pluralidade das áreas de conhecimento, que se distingue do conceito da universidade de áreas;

b) indissociabilidade entre ensino, pesquisa e extensão, a nfvel interno da instituiçăo;

c) existência de uma carreira docente vinculada à sua capacitação, mérito e avaliaçäo de desempenho".

A Universidade para exercitar essas qualidades essenciais deve dispor também de um preceito fundamental que $\hat{c}$ a sua autonomia, que nảo deve ser entendida como uma independencia absolnta da sociedade pcla qual foi criada e à qual deve servir, mas como liberdade de planejar e gerir suas atividades, assumindo a responsabilidade pelos resultados alcançados.

Neste processo de integraçäo da universidade com a sociedade 6 essencial também a existência de um processo avaliatório, onde possam ser controladas as atividades de ensino superior e os recursos canalizados para essas instituiçōes.

Evidentemente este processo de avaliaçáo deve ser feito por mecanismos apropriados que não afetem a desejada autonomia universitária.

\subsection{A evoluçấo dos cursos e vagas}

O número de cursos ministrados nas diversas Instituiçôes de Ensino Superior e o número de vagas nelas oferecida's vêm tendo um acentuado crescimento ao longo dos anos. Dos poucos cursos oferecidos na época do Império, passamos no ano de 1987 para 4.188 cursos com 447.345 vagas, o que representa uma média 106,82 vagas por curso. Destes 4.188 cursos, 1.921 estâo em instituiçōes públicas e 2.267 em entidades privadas, sendo ainda 2.031 deles ministrados em Universidades, $492 \mathrm{em}$ Federaçōes de Escolas e Faculdades Integradas e 1.665 em Estabelecimentos Isolados.

No quadro n 3 temos a evoluçăo dos cursos e vagas oferecidas nas Instituiçốes de Ensino Superior do pafs, no período de 1970/1987. 
QUADRO N³

EVOLUÇĀO DO NÚMERO DE CURSOS E VAGAS OFERECIDAS NA
GRADUAÇÄO DAS IES DO PAÍS.

\begin{tabular}{c|c|c|c|c|c}
\hline \multirow{2}{*}{ ANO } & \multicolumn{2}{|c|}{ Cursos oferecidos } & \multicolumn{2}{c|}{ Vagas oferecidas } & \multirow{2}{*}{ Vagas/cunso } \\
\cline { 2 - 5 } & Número & Indice & Número & Indice & \\
\hline 1970 & 2166 & 100,0 & 145.000 & 100,0 & 66,94 \\
1975 & 3602 & 166,3 & 348,227 & 240,2 & 96,68 \\
1980 & 4079 & 188,3 & 409.000 & 282,1 & 100,27 \\
1985 & 3923 & 181,1 & 430.482 & 296,9 & 109,73 \\
1986 & 4045 & 186,7 & 442,309 & 305,0 & 109,35 \\
1987 & 4188 & 193,4 & 447,345 & 308,5 & 106,82 \\
\hline
\end{tabular}

Fonte: SEEC-MEC

Enquanto os cursos oferecidos cresceram nesse perfodo de $93,40 \%$, as vagas oferecidas para ingresso tiveram um acréscimo de $208,50 \%$, o que produriu uma melhoria na produtividade dos mesmos de 66,94 vagas/curso para 106,82 vagas/curso.

Tratando-se, agora, do total de vagas dos diversos cursos das IES brasileiras e não somente das vagas oferecidas para ingresso de alunos pelo vestibular, teremos o total de estudantes de cursos de graduaçăo. $O$ quadro $n^{\circ} 4$, a seguir, mostra a evoluçäo desse total.

\section{QUADRO N4}

EVOLUÇÃO DO NÚMERO DE ALUNOS MATRÍCULADOS NOS CURSOS DE GRADUAÇĀO DAS IES DO PAÍS, POR NATUREZA.

\begin{tabular}{c|c|c|c|c|c}
\hline \multirow{2}{*}{ ANO } & \multicolumn{2}{|c|}{ Universidades } & \multicolumn{2}{c|}{$\begin{array}{c}\text { Federagato de Fscolas c } \\
\text { Fistabelecimentos Isolados }\end{array}$} & \multirow{2}{*}{ TOTAL } \\
\cline { 2 - 5 } & Número & $\%$ & Número & $\%$ & \\
\hline 1970 & 244.213 & 53,54 & 211.921 & 46,46 & 456.134 \\
1975 & 426.000 & 44,05 & 541.000 & 55,95 & 967.000 \\
1980 & 642.000 & 47,73 & 703.000 & 52,27 & 1.345 .000 \\
1985 & 671.977 & 49,14 & 695.632 & 50,86 & $1,367.609$ \\
1986 & 722.863 & 50,97 & 695.333 & 49,03 & $1,418.196$ \\
1987 & 761.236 & 51,77 & 709.319 & 48,23 & 1.470 .555 \\
\hline
\end{tabular}

Fonte: SFEC-MIC

Istoé, possufa o paf́s em 1987 um total de 1.470.555 alunos matriculados em Instituiçóes de Ensino Superior, em cursos de graduaçäo, sendo $51,77 \%$ em Universidades e $48,23 \%$ em Federaçōes de Escolas e Estabelecimentos Isolados. Embora o sistema de ensino superior brasileiro seja sempre enfocado sobre o prisma das Universidades, vemos, na realidade, que metade dele $e$ desenvolvido em estabelecimentos isolados, de natureza pública ou privada. 
Em relaçāo à distribuiçāo dos alunos matriculados nas IES do país entre cntidades públicas ou particulares, observamos, vide quadro $n^{\circ} 5$, umi predoninância das instițiços privades.

\section{QUADRO Na 5}

EVOLUÇĀO DO NUMERO DE ALUUNOS MATRICUI_ADOS NOS CURSOS DE GRADUAÇĀO DAS IES DO PAÍS POR DEPENDÉNCIA ADMINISTRATIVA

\begin{tabular}{|c|c|c|c|c|c|}
\hline \multirow{2}{*}{$\mathrm{AND}$} & \multicolumn{2}{|c|}{ ILSFúblimb } & \multicolumn{2}{|c|}{ ITS pertinulatas } & \multirow{2}{*}{ TOTAL } \\
\hline & रर्पिमीक & $\gamma$ & Núfae巾 & $\%$ & \\
\hline $\begin{array}{l}1970 \\
1545 \\
1960 \\
1985 \\
1956 \\
1987\end{array}$ & $\begin{array}{l}215077 \\
376,000 \\
490,000 \\
556,690 \\
57.642 \\
504.969\end{array}$ & $\begin{array}{l}47,15 \\
39,68 \\
36,65 \\
40,70 \\
40,73 \\
39,76\end{array}$ & $\begin{array}{l}241.05 T \\
591.500 \\
852.000 \\
610.920 \\
040564 \\
045.56\end{array}$ & $\begin{array}{l}52,85 \\
61,12 \\
61,35 \\
59,30 \\
59,27 \\
60,22\end{array}$ & $\begin{array}{r}456.134 \\
967.000 \\
1,345000 \\
1,367,609 \\
1.416 .194 \\
1.470 .553\end{array}$ \\
\hline
\end{tabular}

FOALE, SEEC MEC

Ccrca de $60 \%$ do alunado de graduaçăa do pals estudarn em enlidades particulares, contra 40\% on inslituiçōes públicas. No periodo 70/84 continuou a tendênça de prịatizaçăa do ensino acclerada pola refortna universilária.

Comparando com ns dados de 1940 , observamus que, ano bltimos 50 anos, o nímera de vagas para acesso ao ensino superior to Btasil passou de 9.200 para 447.345 (crescimento $4.800 \%$ ), enquanto o nțmera de alunos matriculados de 27.571 para 1.470555 (acrescimento $5300 \%$ ).

De acordo com a publicaçăo Sinopse do Ensino Stperior-Gradtaģado, do MEC/1987, a distribuiģán dos 1.470 .555 alumas matriculados no tosino superior abedecia as seguintes arcas do cordhecimento:

$\begin{array}{lr}\text { Ciências Sociais Aplicadas } & 38,01 \% \\ \text { Ciencias Humanas } & 19,05 \% \\ \text { Cienncias da Saude } & 11,59 \% \\ \text { EnjentariaTecnologia } & 9,84 \% \\ \text { Ciencias Exatas } & 8,92 \% \\ \text { Letras e Artes } & 8,50 \% \\ \text { Ciencias Agrárias } & 2,74 \% \\ \text { Citucias Biologitus } & 1,35 \%\end{array}$

\section{3,4. A ręlaçūo oferta x procura}

O qúmero de alunos que cursa o ensino superior em relaçăo à populaçāo do país wen crescendo inuito lentamente no Brasil e seu valor se situn muito abaiko dos ofveis de outros paises detecriolvidos. Scgundo dados do Statistical Year Book, em 1985, eram as seguintes as proporçes de alunos tha Univcrsidade por 10 ofo habitantes: 
Brasil

11 alunos por mil habitantes

Argentina

20

Venezuela

$21 \quad n$

Europa

22

Canadá

Estados Unidos

n

Estes dados mostram a grande distância que deverá ser percorrida para que o Brasil atinja niveis desejáveis de pessoas cursando a Universidade e indica que sāo necessários imensos recursos para que o país aproxime-se dos indices dos pafses desenvolvidos.

$\mathrm{Na}$ realidade, no entanto, o quadro näo é nada animador quando verificamos a evoluçăo do número de conclusôes do $2^{\circledR}$ grau e o número de inscriçóes no concurso vestibular das diversas instituiçöes de ensino superior do pafs. (Vide quadro $\mathrm{n}^{2} 6$ ).

QUADRO No6

EVOLUÇĀO DO NÚMERO DE CONCLUSÖES DO $2^{\circ}$ GRAU E DAS INSCRIÇÕES NO VESTIBULAR DAS IES DO PAÍS.

\begin{tabular}{c|c|c|c|c|c}
\hline \multirow{2}{*}{ ANO } & \multicolumn{2}{|c|}{ Conclusoes do 20 grau } & \multicolumn{2}{c|}{ Insc. no Vestibular } & \multirow{2}{*}{$\begin{array}{c}\text { Insc. } \\
\text { Concl. }\end{array}$} \\
\cline { 2 - 5 } & Número & $\%$ & Número & $\%$ & \\
\hline 1970 & 225.913 & 100,0 & 328.931 & 100,0 & 1,46 \\
1975 & 368.479 & 163,1 & 781.190 & 237,5 & 2,12 \\
1980 & 597.000 & 264,3 & 1.750 .000 & 532,0 & 2,93 \\
1985 & 557.727 & 246,88 & 1.514 .341 & 460,4 & 2,72 \\
1986 & 512.383 & 226,81 & 1.737 .794 & 528,3 & 3,39 \\
1987 & - & - & 2.193 .851 & 666,9 & - \\
\hline
\end{tabular}

Fonte: SIEEC-MEC

A acentuada diferença entre o número de conclusōes do $2^{\circ}$ grau e o número de inscriçốcs no concurso vestïbular é proveniente do elevado número de candidatos que, impedidos de chegar à Universidade a cada ano, retornam no concurso seguinte, numa nova tentativa de ingresso, além de outros candidatos que, havendo conclufdo o $2^{2}$ grau há mais tempo, ingressaram no mercado de trabalho por necessidade de sobrevivência e agora buscam uma formaçăo de nfvel superior.

Os dados do quadro $\mathrm{n}^{2} 7$ mostram, de mancira assustadora, a evoluçẩo crescente do número de alunos sem acesso ao ensino supcrior, por limitação das vagas oferecidas pelas instituiçōes.

Em 1970, para cada 100 vagas oferecidas no ensino superior do país, existiam 227 candidatos inscritos e, em 1987, para o mesmo número de vagas concorreram 490 candidatos. Mesmo considerando que onemero de candidatos inscritos no vestibular inclui uma dupla contagem, já que um mesmo indivíduo pode fazer mais de um vestibular, temos de convir que é alarmante c preocupante a impossibilidade de 1.746 .516 jovens terem acesso à universidade, somente no ano de 1987. 
QUADRO N27

EVOLUÇÃO DO NÚMERO DE INSCRIÇŌES NO VESTIBULAR E DAS VAGAS OFERECIDAS NOS CURSOS DE GRADUAÇÄO DAS IES DO PAÍS.

\begin{tabular}{c|c|c|c|c}
\hline ANO & $\begin{array}{c}\text { Inseriçdes no } \\
\text { Vestibular }\end{array}$ & $\begin{array}{c}\text { Vagas } \\
\text { oferecidas }\end{array}$ & $\begin{array}{c}\text { Impedidos } \\
\text { de acesso }\end{array}$ & $\begin{array}{c}\text { Relaçâo } \\
\text { candidato/vaga }\end{array}$ \\
\hline 1970 & 328.931 & 145.000 & 183.931 & 2,27 \\
1975 & 781.190 & 348.227 & 432.963 & 2,24 \\
1980 & 1.750 .000 & 409.000 & 1.341 .000 & 4,28 \\
1985 & 1.514 .341 & 430.482 & 1.083 .859 & 3,52 \\
1986 & 1.737 .794 & 442.309 & 1.295 .485 & 3,93 \\
1987 & 2.93 .861 & 447.345 & 1.746 .516 & 4,90 \\
\hline
\end{tabular}

Fonte: SEEC-MEC

3.5. As causas da demanda crescente

A demanda crescente pcla educaçäo universitária está intimamente ligada, entre outros, aos seguintes fatores:

- urbanizaçăo da populaçăo do pais;

- elevaçâo do padrão de vida de parte da populaçăo;

- descjo de ascensāo social;

- necessidade de pessoal especializado no mercado de trabalho e

- tendência à democratização das condiçōes de vida no país que, por certo, guardam uma estreita relaçäo com o grau de desenvolvimento industrial atingido, influenciando sua população a buscar níveis mais elevados de satisfação cuitural.

A grande urbanizaçăo havida na população do pafs nos últimos 45 anos permitiu um crescimento extraordinário da escola de $1^{\circ} \mathrm{e} 2^{\circ}$ graus que, juntamente com os exames supletivos, colocaram grandes contigentes às portas da Universidade em busca do ensino superior.

No quadro $\mathrm{n}^{2} 8$ vemos que, de 1940 a 1985, houve uma inversão entre a população urbana e rural do pais.

$$
\text { QUADRO N } 8
$$

EVOLUÇĀO DA POPULAÇĀo URBANA, RURAL E TOTAL DO PAís.

\begin{tabular}{l|c|c|c|c|c|c}
\hline \multirow{2}{*}{ ANO } & \multicolumn{2}{|c|}{ URBANA } & \multicolumn{2}{c|}{ RURAL } & \multicolumn{2}{c}{ TOTAL } \\
\cline { 2 - 7 } & $(1000)$ & $\%$ & $(1000)$ & $\%$ & $(1000)$ & $\%$ \\
\hline \multirow{2}{*}{1940} & 12.880 & 31,2 & 28.356 & 68,8 & 41.236 & 100,0 \\
1950 & 18.782 & 36,2 & 33.162 & 63,8 & 51.944 & 100,0 \\
1960 & 31.303 & 44,7 & 38.767 & 55,3 & 70.070 & 100,0 \\
1970 & 52.084 & 55,9 & 41.054 & 44,1 & 93.138 & 100,0 \\
1980 & 89.436 & 67,6 & 38566 & 32,4 & 119.002 & 100,0 \\
1985 & 95.473 & 72,7 & 35.938 & 27,3 & 131.411 & 100,0 \\
\hline
\end{tabular}

Fonte. FIBGB 
De $31,2 \%$ de população urbana em 1940 , passamos para $72,7 \%$, em 1985 , enquanto de $68,8 \%$ de populaçäo rural $\mathrm{cm} 1940$ regredimos para $27,3 \%$, cm 1985 . Esta concentraçäo de populaçăo nas cidades, além do crescimento da própria populaçăo urbana, acentuou a procura por vagas no ensino superior, especialmente considerando que o segmento jovem deste total e bastante expressivo.

Em conseqüência do acentuado desenvolvimento industrial, parte da populaçảo do paf́s atingiu real crescimento de renda e uma conseqữente elevaçäo do padräo de vida. Com isto, camadas sociais que, anteriormente, se contenlavam com menores niveis de educaçăo, passam a aspirar à instrução superior. À medida em que o país atinge maiores nfveis de desenvolvimento, o anseio por educaçāo se cleva e os valores dominantes da sociedade influenciam fortemente os jovens e adultos a buscarem o ingresso na universidade.

Por outro lado, verifica-se que nem sempre o valor do conhecimento e o fato mais determinante na busca do cnsino superior. $\mathrm{O}$ acesso à Universidade tem sido para muitas famflias de classe média urbana uma mancira para a ascensäo social, especialmente através dos cursos ditos de prestfgio. A mobilidade social conseguida por aqueles que galgam os degraus universitários representa a possibilidade de níveis mais elevados de renda, como também a aquisiçăo de uma maior respeitabilidade e credibilidade no âmbito da sociedade.

A necessidade de pessoal especializado no mercado de trabalho tambem tem sido fator a exercer pressäo para o acesso ao ensino superior, uma vez que, com o desenvolvimenta econômico, todas as atividades profissionais tornaram-se extremamente especializadas. Este nivel de conhecimentos técnicos e cientfficos somente 6 adquirido nos estabelecimentos de ensino superior. E aqueles poucos que recebem estas formas de treinamento vencem salários substancialmente mais elevados.

Esta associação entre o nível de educação c os salários obtidos é mostrada no gráfico a seguir, onde as profissōes de nfvel superior percebem as maiores remuneraçōes, especialmente na faixa de idade de 45-54 anos, quando se admite ter o profissional a sua maior produtividade associada a uma larga experiência.

À medida em que o nível de instrução cai, os salários sofrem também redução substancial. Embora o gráfico apresentado scja de 1969, a estrutura básica dos perfís de renda permanece válida, especialmente agora, quando as prolissōes de alta especializaçāo galgam o topo das pirâmides salariais.

\section{CONDICIONANTES SÓCIO-ECONÓMICOS}

Em todos os concursos vestibulares realizados em 1987 foram oferecidas, pelas Instituiçöes de Ensino do País, 447.345 vagas, para as quais inscreveram-se 2.193.861 candidatos, representando uma relaçäo de 4,90 candidatos por vaga. Esta traumatizante disputa por uma vaga no ensino superior brasilciro, que se repete semestralmente, é influenciada por condicionantes sociais e econômicos que tendem claramente para aqueles que pertencem às classes alta e media, $\mathrm{cm}$ detrimento das classes mais baixas.

Moura Castro e Costa Ribeiro $\mathrm{cm}$ seu trabalho Desizualdade social e acesso à Universidade - Dilemas e tendências (1979), expressam com muita propriedade este problema, quando afirmam:

"Em qualquer pats, em qualquer regime politico e en qualquer nfvel educacional, as probabilidades de êxito na escola estäo condicionadas à origem social dos altunos. Um bom nímero de estudos revela que os indicadores de origem sócio-econônicos säo as variáveis 
GRÁFICO № 1

HOMENS: SALARIO SEMANAL POR NIVEL DE EDUCAÇÃO E IDADE (em Cr\$ de 1969)

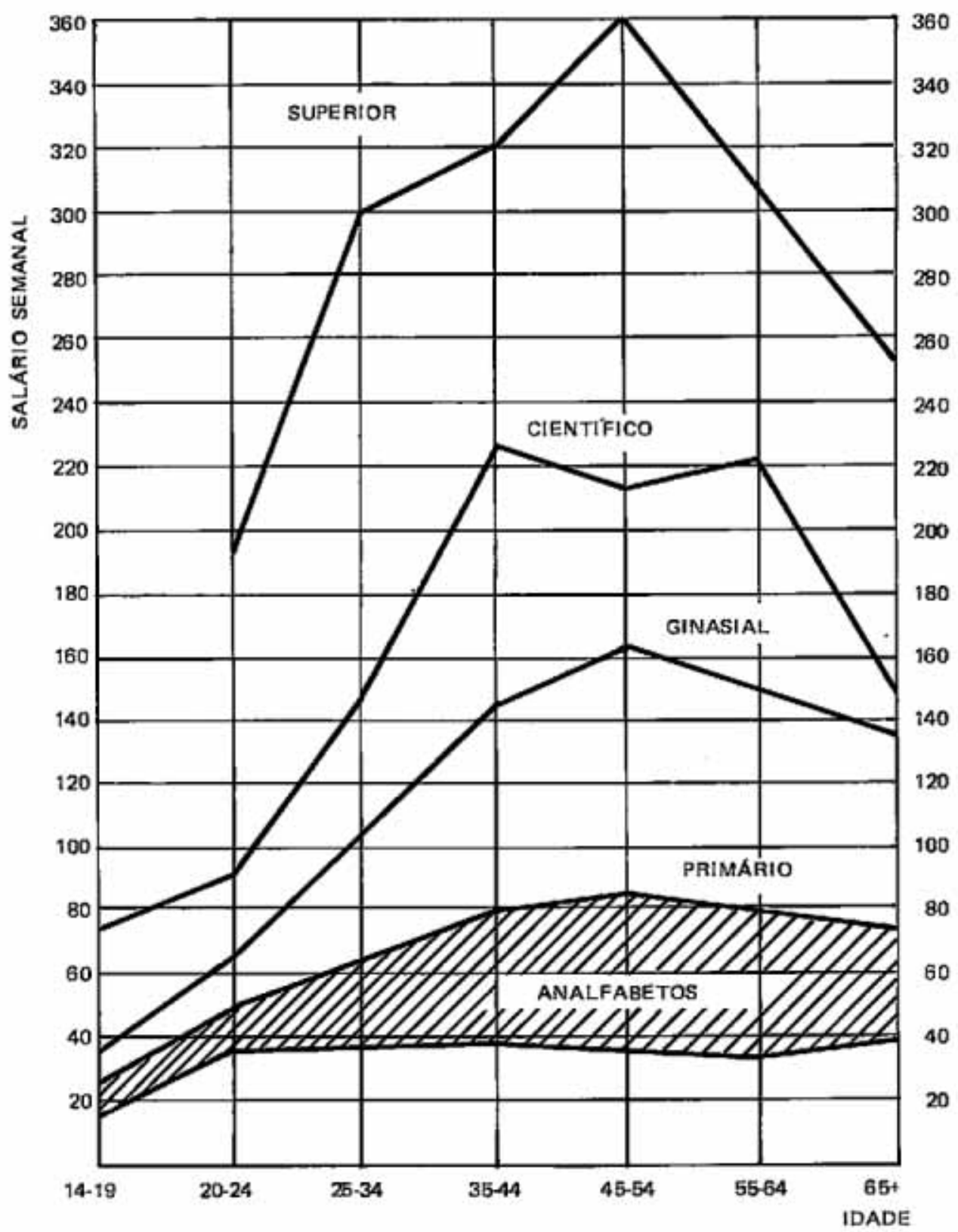

Fonte: LANGONI, C.G. (1975) - A economia da transformaçâo. p.141. 
de maior valor preditivo do desempenho escolar. $O$ vestibular năo é exceçäo. Näo só a presença dos vestibulandos é proporcionalmente menor quanto mais baixo o nivel social, cono também säo menores as suas chances de aprovaçäo nos exames."

$\mathrm{Na}$ rcalidade, observamos que estes condicionantes existem em um bom número e exercem uma perversa influência na seleçăo daqueles que teräo acesso ao $3^{2}$ grau de ensino.

Constatamos que alunos provenientes de escolas particulares passam mais no vestibular do que os candidatos oriundos das escolas públicas. Aqueles que estudam durante o dia levam nftida vantagem sobre os que freqüentam a escola noperiodo noturno. Os filho de pais de nfvel superior têm mais chance de acesso do que os filhos de pais de educação primária. Os ocupantes de altos cargos administrativos colocam mais seus filhos na Universidade do que aqueles que exercem funçōes semi-especializadas. Enfim, os ricos têm mais vez de usufruir do ensino público e gratuito do que os pobres.

Este quadro é encontrado em todo o território do pafs, apresentando situaçöes em regióes menos desenvolvidas e aspectos menos drásticos nos centros industriais. Para um acompanhamento destes condicionantes sócio-econômicos procedemos a uma análise dos relatórios dos concursos vestibulares de oito Universidades brasileiras, escolhidas de modo a seguir uma distribuição em várias regiōes do pafs, abrangendo instituiçổes federais, estaduais e particulares.

Evidentemente, a situaçāo ideal scria a análise dos dados sócio-econômicos dos vestibulares de todas as instituiçöes de ensino superior do pafs, mas $\mathrm{em}$ virtude da magnitude dos dados a processar e das dificuldades de tê-los disponiveis, optamos por uma amostragem que procura cobrir as regiôes c os tipos de estabelecimentos existentes.

O Ministério da Educaçảo vem recomendando aos Estabelecimentos de Ensino Superior do país, através das Portarias Ministeriais anuais sobre o concurso vestibular, o recolhimento e a análise de informaçôes sócio-culturais e de identificaçāo dos candidatos, por ocasião de sua inscriçăo no concurso, com a finalidade de levantar dados a respeito de clicntela destas instituiçöes.

Os dados colhidos por estes questionários indicam, em námeros absolutos e $\mathrm{cm}$ percentuais, as respostas de todos os candidatos inscritos e dos aprovados e representam uma massa de elementos que pode ser explorada com mais profundidade, para diagnosticar as causas das graves distorçöes que vêm ocorrendo na entrada do $3^{2}$ grau de ensino.

Para a analise dos dados colhidos como amostragem, escolhemos oito Universidades espalhadas do Rio Grande do Sul ao Ceará c com características diversas, conforme mostrado a seguir:

a) Fundaçåo Universidade do Rio Grande - vestibular 1982 IES federal/localizada no interior do Estado/Região sul;

b) Universidade Federal de Santa Catarina - vestibular 1988 IES federa//ocalizada na capital do Estado/Regiāo sul;

c) Universidade Estadual Paulista - vestibular 1987 IES cstadual/localizada na capital c intcrior do Estado/Regiāo sul;

d) Universidade Federal do Rio de Janciro - vestibular 1988 IES federal/localizada na capital do Estado/Região sudeste;

e) Universidade Federal de Pernambuco - vestibular 1989 IES federal/localizada na capital c interior do Estado/Regiăo nordeste; 
f) Universidade Federal do Rio Grande do Norte - vestibular 1982

IES federa//localizada na capital do Estado/Regiäo nordeste;

g) Universidade Estadual do Ceará - vestibular 1988

IES estadual/localizada na capital $\mathrm{c}$ interior do Estado/Regiāo nordeste;

h) Universidade de Fortaleza - vestibular 1989

IES particular/localizada na capital do Estado/Regiấo nordeste.

Em cada um dos relatórios com os dados sócio-econômicos dos inscritos e dos aprovados nos respectivos concursos vestibulares, colhemos as informaçōes necessárias para verificar as influencias, no desempenho de cada candidato, dos aspectos ligados a sua origem social e ao seu padrăo de vida. Constatamos que alguns dos fatores acima referidos podem ter uma grande influência na performance de um candidato que busca o acesso à Universidade, como:

- o tipo de escola em que cursou o $1^{2}$ e $2^{\circ}$ graus;

- o perfodo $\mathrm{em}$ que freqüentou o $2^{\circ} \mathrm{grau}$;

- o grau de escolaridade dos pais;

- a ocupaçăo principal do pai ou responsável e

- a renda mensal da famflia.

Estas influências são verificadas e comentadas nos itens subseqũentes, onde os dados numéricos apresentados falam mais alto do que os argumentos que possam ser levantados.

\subsection{Escola pública $x$ escola particular}

De cada um dos relatórios das oito Universidades anteriormente referidas, foram retirados os dados a seguir expostos:

a) Fundaçäo Universidade do Rio Grande - RGS

Escola em que cursou o $2^{2}$ grau

\begin{tabular}{l|c|c|c|c|c}
\hline Alternativas & Inscritos & $\%$ & Aprovados & $\%$ & $\begin{array}{c}\text { Percentual } \\
\text { relativo }\end{array}$ \\
\hline Escola pública & 1488 & 55,45 & 462 & 56,47 & 31,90 \\
Escola particular & 855 & 33,03 & 282 & 34,47 & 32,98 \\
Escola páblica e particular & 285 & 11,01 & 74 & 9,04 & 25,96 \\
\hline
\end{tabular}

Fonte: Análise das informaçōes sócio-educacionais - Vestibular 82 - Universidade do Rio Grande.

“A maioria dos candidatos éegressa de escola pública, masé entre os quecursaramescolas particulares que o percentual relativo é methor. Nos dois cursos (Medicina e Oceanologia) onde a disputa de vagas foi maior, a escola particular classificou maior número de candidatos." 
b) Universidade Federal de Santa Catarina - SC

Como fez seus estudos de $1^{2} \mathrm{e} 2^{2}$ grau?

\begin{tabular}{r|c|c|c|c|c}
\hline \multirow{2}{*}{$\begin{array}{l}\text { Escola freqūentada } \\
\text { (toda ou a maior parte) }\end{array}$} & \multicolumn{2}{|c|}{ Inscritos } & \multicolumn{2}{|c|}{ Aprovados } & \multirow{2}{*}{$\begin{array}{c}\text { Pcrcentual } \\
\text { Relativo }\end{array}$} \\
\cline { 2 - 5 } & Total & $\%$ & Total & $\%$ & \\
\hline Primeiro grau: Páblica & 9.460 & 60,9 & 1.384 & 51,9 & 14,63 \\
particular & 5.728 & 36,6 & 1.251 & 46,8 & 21,84 \\
\hline Segundo grau: Pública & 6.829 & 43,5 & 1.132 & 42,5 & 16,58 \\
Particular & 8.008 & 51,1 & 1.455 & 54,6 & 18,17 \\
\hline
\end{tabular}

Fonte: Relatorio Vestibular - 1988 / Universidade Federal de Santa Catarina

c) Universidade Estadual Paulista - SP

Como cursou o $1^{2}$ e o $2^{\circ}$ grau?

\begin{tabular}{|c|c|c|c|c|c|}
\hline \multirow{2}{*}{$\begin{array}{l}\text { Escola freqủentada } \\
\text { (toda ou a maior parte) }\end{array}$} & \multicolumn{2}{|c|}{ Inscritos } & \multicolumn{2}{|c|}{ Aprovados } & \multirow{2}{*}{$\begin{array}{c}\text { Percentual } \\
\text { Relativo }\end{array}$} \\
\hline & Total & $\%$ & Total & $\%$ & \\
\hline $\begin{array}{r}\text { Primciro grau: Pública } \\
\text { Particular }\end{array}$ & $\begin{array}{r}22.993 \\
8.118\end{array}$ & $\begin{array}{l}72,49 \\
25,59\end{array}$ & $\begin{array}{r}2.856 \\
738\end{array}$ & $\begin{array}{l}78,29 \\
20,23\end{array}$ & $\begin{array}{r}12,42 \\
9,10\end{array}$ \\
\hline $\begin{array}{r}\text { Scgundo grau: Pública } \\
\text { Particular }\end{array}$ & $\begin{array}{l}16.036 \\
14.911\end{array}$ & $\begin{array}{l}50,56 \\
47,01\end{array}$ & $\begin{array}{l}21,24 \\
14,55\end{array}$ & $\begin{array}{l}58,22 \\
39,88\end{array}$ & $\begin{array}{r}13,25 \\
9,76\end{array}$ \\
\hline
\end{tabular}

Fonte: Relatório Vestibular 87 - VUNESP

d) Universidade Federal do Rio de Janciro - $R J$

Primeiro e segundo graus foram realizados.

\begin{tabular}{c|c|c|r|r|r}
\hline \multirow{2}{*}{$\begin{array}{c}\text { Escola freqũentada } \\
\text { (toda ou a maior parte) }\end{array}$} & \multicolumn{2}{|c|}{ Inscritos } & \multicolumn{2}{c|}{ Aprovados } & \multirow{2}{*}{$\begin{array}{c}\text { Percentual } \\
\text { Relativo }\end{array}$} \\
\cline { 2 - 5 } & Total & $\%$ & \multicolumn{1}{c|}{ Total } & $\%$ & \\
\hline Primciro grau: Páblica & 13.139 & 47,42 & 912 & 32,43 & 6,94 \\
Particular & 14.567 & 52,58 & 1.900 & 67,57 & 13,04 \\
\hline Segundo grau: Páblica & 10.451 & 37,96 & 885 & 31,63 & 8,47 \\
Particular & 17.082 & 62,04 & 1.913 & 68,37 & 11,20 \\
\hline
\end{tabular}

"Nota-se que cerca de ${ }^{2} / 3$ dos alunos classificados responderam que realizaram seus estudos de primeiro e segundo graus em escolas particulares."

Fonte: Perfil sócio-cultural dos candidatos classificados no concurso de setembro 88 - UFRJ. 
e) Universidade Federal de Pernambuco - PE

Estudou o $1^{2} \mathrm{e} o 2^{2}$ grau em que colégio?

\begin{tabular}{c|r|r|r|r|r}
\hline \multirow{2}{*}{ Escola freqücntada } & \multicolumn{2}{|c|}{ Inscritos } & \multicolumn{2}{c|}{ Aprovados } & \multirow{2}{*}{$\begin{array}{c}\text { Percentual } \\
\text { Relativo }\end{array}$} \\
\cline { 2 - 5 } & \multicolumn{1}{|c|}{ Total } & $\%$ & Total & $\%$ & \\
\hline $1^{\circ}$ grau: Páblico & 6.326 & 30,20 & 708 & 19,10 & 11,19 \\
Particular & 14.620 & 69,80 & 2.997 & 80,90 & 20,50 \\
\hline $2^{\circ}$ grau: Público & 5.802 & 27,70 & 711 & 19,20 & 12,25 \\
Particular & 15.144 & 72,30 & 2.994 & 80,80 & 19,77 \\
\hline
\end{tabular}

"É importante ressaltar que, embora as escolas públicas do Estado formem mais estudantes de $2^{\circ}$ grau do que as escolas privadas, poucos de seus estudantes se inscreveram para o concurso e pouquíssimos conseguiram exito no vestibular.

Pode-se afimar que a fragilidade da estrutura do ensino do Estado nega aos estudantes mais pobres o necessário apoio para que os mesmos possam competir acadêmicamente com aqueles que pagam pelo ensino privado".

Fonte: Vestibular 89-Relatorio Analítico/COVEST - UFPE

f) Universidade Federal do Rio Grande do Norte - RGN

Escola em que estudou no $1^{\circ} \mathrm{e} \mathrm{no} 2^{2} \mathrm{grau}$.

\begin{tabular}{c|r|r|r|r|r}
\hline \multirow{2}{*}{$\begin{array}{c}\text { Escola freqũcntada } \\
\text { (toda ou a maior parte) }\end{array}$} & \multicolumn{2}{|c|}{ Inscritos } & \multicolumn{2}{c|}{ Classificados } & \multirow{2}{*}{$\begin{array}{c}\text { Percentual } \\
\text { Relativo }\end{array}$} \\
\cline { 2 - 5 } & \multicolumn{1}{|c|}{$\mathrm{N}^{2}$} & $\%$ & \multicolumn{1}{c}{$\mathrm{N}^{2}$} & $\%$ & \\
\hline $1^{\circ}$ grau: Oficial & 10.075 & 66,64 & 1.213 & 56,71 & 12,04 \\
Particular & 3.669 & 24,27 & 739 & 34,55 & 20,14 \\
Oficial + Particular & 1.375 & 9,09 & 187 & 8,74 & 13,60 \\
\hline $2^{\circ}$ grau: Oficial & 1.310 & 68,30 & 1.319 & 61,70 & 12,79 \\
Particular & 3.955 & 26,20 & 718 & 33,58 & 18,15 \\
Oficial + Particular & 830 & 5,50 & 101 & 4,72 & 12,17 \\
\hline
\end{tabular}

"Os melhores percentuais de desempenho vêm sido mantidos pelos candidatos que cursaram todos os anos em escola particular, tendo, inclusive, aumentado este ano a diferença em relaçdo ds outras alternativas.

Analisando a tabela de percentuais de desempenho, verifica-se que quanto mais tempo o aluno estudou em escola oficial, menor o seu aproveitamento no vestibular."

Fonte: Estudo analítico de dados sócio-econômico-culturais dos candidatos ao concurso vestibular da URFN 1982. 
g) Universidade Estadual do Ceara - CE

Escola cursada no $1^{\mathrm{R}}$ e no $2^{\mathrm{a}}$ grau.

\begin{tabular}{c|c|c|r|r|c}
\hline \multirow{2}{*}{$\begin{array}{c}\text { Escola freqücntada } \\
\text { (toda ou a maior parte) }\end{array}$} & \multicolumn{2}{|c|}{ Inscritos } & \multicolumn{2}{c|}{ Aprovados } & \multirow{2}{*}{$\begin{array}{c}\text { Percentual } \\
\text { Relativo }\end{array}$} \\
\cline { 2 - 5 } & Total & $\%$ & \multicolumn{1}{|c|}{ Total } & $\%$ & \\
\hline Primeiro grau: Páblica & 3.505 & 40,0 & 806 & 29,50 & 23,00 \\
Particular & 5.181 & 59,0 & 1.915 & 70,10 & 36,96 \\
\hline Segundo grau: Páblica & 2.870 & 32,70 & 656 & 24,00 & 22,86 \\
Particular & 5.724 & 65,10 & 2.056 & 75,20 & 35,92 \\
\hline
\end{tabular}

Fonte: Perfil dos candidatos aos cursos da UECE - CEV/1988.

h) Universidade de Fortaleza - CE

Como fez seus estudos de $1^{\circ}$ e de $2^{\circ}$ grau?

\begin{tabular}{c|r|r|r|r|c}
\hline \multirow{2}{*}{$\begin{array}{c}\text { Escola frequientada } \\
\text { (toda ou a maior parte) }\end{array}$} & \multicolumn{2}{|c|}{ Inscritos } & \multicolumn{2}{c|}{ Aprovados } & \multirow{2}{*}{$\begin{array}{c}\text { Percentual } \\
\text { Relativo }\end{array}$} \\
\cline { 2 - 5 } & Total & $\%$ & Total & $\%$ & \\
\hline Primciro grau: Páblica & 1.094 & 24 & 141 & 14 & 12,89 \\
Particular & 3.458 & 74 & 881 & 85 & 25,48 \\
\hline Scgundo grau: Pública & 742 & 16 & 97 & 10 & 13,07 \\
Particular & 3.806 & 81 & 917 & 88 & 24,09 \\
\hline
\end{tabular}

"Constata-se uma transferência de altunos da escola pública para a escola privada quando da passagem do primeiro para o segundo grati. A maioria dos ahunos inscritos e uma percentagem maior ainda dos aprovados proven da escola particular. Os alunos provenientes da escola particular apresentam um desempenho melhor (25\% de aprovados) do que os originários de escola pública (13\% de aprovados)."

Fonte: O Concurso Vestibular na Universidade de Fortaleza - MAIO/89.

Sobre o conjunto de dados estatísticos referentes à escola freqũentada pelos inscritos e aprovados no $1^{\circ} \mathrm{e} 2^{a}$ graus de ensino, podem ser feitas as seguintes observaçōes:

a) $\mathrm{cm}$ todas as universidades constata-se uma transferência de alunos da escola pública para a cscola privada quando da passagem do primeiro para o segundo grau;

b) na quase totalidade das universidades investigadas, a maioria dos alunos inscritos e uma percentagem maior ainda dos aprovados, provém da escola particular; 
c) os alunos provenientes da escola privada apresentam $\mathrm{em}$ todos os exames um desempenho melhor do que os originários da escola oficial;

d) apenas na UNESP-SP os candidatos da escola pública apresentaram uma melhor performance do que os alunos da escola privada, o que creditamos a boa estrutura do cnsino oficial no Estado de Săo Paulo.

\subsection{Turno que cursou $02^{\circ}$ grau}

Indiscutivelmente, os alunos que coriclufram o $2^{2}$ grau no turno da noite apresentaram condiçöes mais desfavoráveis de aprendizado, já que durante o dia exercem atividades no mercado como forma de garantir sua sobrevivência.

a) Fundaçâo Universidade do Rio Grande - RGS

Perfodo em que cursou o $2^{\circ}$ grau

\begin{tabular}{c|r|r|r|r|c}
\hline \multirow{2}{*}{ Turno cursado } & \multicolumn{2}{|c|}{ Inscritos } & \multicolumn{2}{c|}{ Aprovados } & \multirow{2}{*}{$\begin{array}{c}\text { Percentual } \\
\text { Relativo }\end{array}$} \\
\cline { 2 - 5 } & Total & $\%$ & Total & $\%$ & \\
\hline Diurno & 1.531 & 59,94 & 571 & 70,23 & 37,22 \\
Noturno & 624 & 24,38 & 130 & 15,99 & 20,83 \\
Ambos & 401 & 15,67 & 112 & 13,77 & 27,93 \\
\hline
\end{tabular}

"O número de inscritos classificados e o percentual relativo levam a concluir que o aluno de curso diumo apresenta melhor desempenho."

Fonte: Análise das informaçöes sócio-educacionais - Vestibular 82 - Universidade do Rio Grande.

b) Universidade Federal de Santa Catarina - SC

Em que turno você fez seu curso de $2^{2}$ grau?

\begin{tabular}{c|c|c|c|c|c}
\hline \multirow{2}{*}{$\begin{array}{c}\text { Turno cursado } \\
\text { (todo ou a maior parte) }\end{array}$} & \multicolumn{2}{|c|}{ Inscritos } & \multicolumn{2}{c|}{ Aprovados } & \multirow{2}{*}{$\begin{array}{c}\text { Percentual } \\
\text { Relativo }\end{array}$} \\
\cline { 2 - 5 } & Total & $\%$ & Total & $\%$ & \\
\hline Diurno & 9.241 & 59,0 & 2.002 & 75,0 & 21,66 \\
Noturno & 6.000 & 38,3 & 613 & 23,0 & 10,22 \\
\hline
\end{tabular}

Fonte: Relatório Vestibular - 1988/Universidade Federal de Santa Catarina. 
c) Universidade Estadual Pautista - SP

Turno $\mathrm{em}$ que cursou o $2^{\circ} \mathrm{grau}$.

\begin{tabular}{|c|c|c|c|c|c|}
\hline \multirow{2}{*}{$\begin{array}{l}\text { Turno cursado } \\
\text { (todo ou a maior parte) }\end{array}$} & \multicolumn{2}{|c|}{ Inscritos } & \multicolumn{2}{|c|}{ Aprovados } & \multirow{2}{*}{$\begin{array}{l}\text { Percentual } \\
\text { Relativo }\end{array}$} \\
\hline & Total & $\%$ & Total & $\%$ & \\
\hline $\begin{array}{l}\text { Diurno } \\
\text { Noturno }\end{array}$ & $\begin{array}{r}24.882 \\
6.242\end{array}$ & $\begin{array}{l}78,45 \\
19,70\end{array}$ & $\begin{array}{r}2.784 \\
808\end{array}$ & $\begin{array}{l}76,32 \\
22,15\end{array}$ & $\begin{array}{l}11,19 \\
12,93\end{array}$ \\
\hline
\end{tabular}

Fonte: Relatório Vestibular 87 - VUNESP

d) Universidade Federal do Rio de Janeiro - UFR

Turno $\mathrm{cm}$ que cursou o segundo grau.

\begin{tabular}{c|r|r|r|r|r}
\hline \multirow{2}{*}{$\begin{array}{c}\text { Turno cursado } \\
\text { (todo ou a maior partc) }\end{array}$} & \multicolumn{2}{|c|}{ Inscritos } & \multicolumn{2}{c|}{ Aprovados } & \multirow{2}{*}{$\begin{array}{c}\text { Percentual } \\
\text { Relativo }\end{array}$} \\
\cline { 2 - 5 } & Total & $\%$ & Total & $\%$ & \\
\hline \multirow{2}{*}{$\begin{array}{c}\text { Diurno } \\
\text { Noturno }\end{array}$} & 22.849 & 82,47 & 2.727 & 96,97 & 11,93 \\
\hline
\end{tabular}

"Observa-se um expressivo contingente de altunos näo classificados que estudaram no periodo notumo. Dos estudantes que estudaram no perfodo diumo $11,93 \%$ foram classificados, ao passo que apenas $1,75 \%$ dos que cursaram o segundo grau no notumo conseguiram ingressar na Universidade."

Fonte: Perfil sócio-cultural dos candidatos classificados no concurso de seleçäo 88 Universidade Federal do Rio de Janciro.

e) Universidade Federal de Pernambuco - UFPE

Terminou o $2^{2}$ grau em que turno?

\begin{tabular}{|c|c|c|c|c|c|}
\hline \multirow{2}{*}{$\begin{array}{l}\text { Turno cursado } \\
\text { (todo ou a maior parte) }\end{array}$} & \multicolumn{2}{|c|}{ Inscritos } & \multicolumn{2}{|c|}{ Aprovados } & \multirow{2}{*}{$\begin{array}{c}\text { Percentual } \\
\text { Relativo }\end{array}$} \\
\hline & Total & $\%$ & Total & $\%$ & \\
\hline $\begin{array}{l}\text { Diurno } \\
\text { Noturno }\end{array}$ & $\begin{array}{r}14.788 \\
6.158\end{array}$ & $\begin{array}{l}70,6 \\
29,4\end{array}$ & $\begin{array}{r}3.175 \\
530\end{array}$ & $\begin{array}{l}85,7 \\
14,3\end{array}$ & $\begin{array}{r}21,47 \\
8,61\end{array}$ \\
\hline
\end{tabular}

Fonte: Vestibular 89 - Relatório Analítico/COVEST-UFPE 
f) Universidade Federal do Rio Grande do Norte - UFRN

Em que turno você cursou o $2^{a}$ grau?

\begin{tabular}{c|r|r|r|r|r}
\hline \multirow{2}{*}{$\begin{array}{c}\text { Turno cursado } \\
\text { (todo ou a maior parte) }\end{array}$} & \multicolumn{2}{|c|}{ Inscritos } & \multicolumn{2}{c|}{ Aprovados } & \multirow{2}{*}{$\begin{array}{c}\text { Percentual } \\
\text { Relativo }\end{array}$} \\
\cline { 2 - 5 } & Total & $\%$ & Total & $\%$ & \\
\hline Diurno & 6.452 & 39,62 & 1.015 & 56,60 & 15,70 \\
Noturno & 7.900 & 48,51 & 413 & 24,03 & 5,40 \\
\hline
\end{tabular}

Fonte: Estudo analítico de dados sócio-econômico-culturais dos candidatos ao Concurso Vestibular da UFRN - 1982.

g) Universidade Estadual do Ceard - UECE

Turno em que cursou o $2^{2}$ grau

\begin{tabular}{c|c|c|c|c|c}
\hline \multirow{2}{*}{$\begin{array}{c}\text { Turno cursado } \\
\text { (todo ou a maior parte) }\end{array}$} & \multicolumn{2}{|c|}{ Inscritos } & \multicolumn{2}{c|}{ Aprovados } & \multirow{2}{*}{$\begin{array}{c}\text { Percentual } \\
\text { Relativo }\end{array}$} \\
\cline { 2 - 5 } & Total & $\%$ & Total & $\%$ & \\
\hline Diurno & 6.924 & 69,4 & 2.421 & 88,6 & 34,97 \\
Noturno & 2.486 & 29,1 & 296 & 10,8 & 11,91 \\
\hline
\end{tabular}

Fonte: Perfil dos candidatos aos cursos da UECE - CEV/1988.

h) Universidade de Fortaleza - CE

Turno $\mathrm{cm}$ que cursou o $2^{\circ}$ grau

\begin{tabular}{c|r|r|r|r|r}
\hline \multirow{2}{*}{$\begin{array}{c}\text { Turno cursado } \\
\text { (todo ou a maior partc) }\end{array}$} & \multicolumn{2}{|c|}{ Inscritos } & \multicolumn{2}{c|}{ Aprovados } & \multirow{2}{*}{$\begin{array}{c}\text { Percentual } \\
\text { Relativo }\end{array}$} \\
\cline { 2 - 5 } & Total & $\%$ & Total & $\%$ & \\
\hline Diurno & 3.925 & 84 & 965 & 93 & 24,59 \\
Noturno & 703 & 15 & 57 & 6 & 8,11 \\
\hline
\end{tabular}

"A grande maioria dos candidatos inscritos e aprovados cursou o $2^{e}$ grau no periodo diumo. Os candidatos que freqüentaram o periodo diumo apresentaram uma mellor performance (25\% de aprovados) do que os alunos dos cursos noturnos $(8,11 \%$ de aprovaçäo)."

Fonte: O Concurso Vestibular na Universidade de Fortaleza - MAIO/89. 
Podem ser feitos os seguintes comentários em relaçäo aos dados referentes ao turno em que o candidato cursou o $2^{2}$ grau:

a) expressiva maioria dos candidatos aprovados, em todas as Universidades, fez scus estudos de $2^{\circ}$ grau durante o perfodo diurno;

b) os candidatos que estudaram durante o dia apresentaram um melhor desempenho nas provas do concurso vestibular do que os alunos dos cursos noturnos;

c) apenas na UNESP-SP verificou-se um melhor desempenho de alunos que assistiram aulas durante a noite;

d) convém lembrar que os alunos que cursaram o $2^{a}$ grau durante o dia têm seus estudos custeados pelos pais, enquanto aqueles que freqũentam os cursos noturnos săo responsáveis pelos próprios cstudos e colaboram na renda familiar;

e) os primeiros sáo das classes alta e média, enquanto os outros provém dos estratos mais baixos.

\subsection{Nivel de Instruçäo do pais}

Săo analisados separadamente o grau de escolaridade do pai $\mathrm{e}$ da mảe, em relaçăo a sua influência no desempenho dos candidatos no concurso vestibular, mas ambos são fatores que influem no resultadio.

a) Fundaçäo Universidade do Rio Grande - RGS

Grau de escolaridade do pai

\begin{tabular}{|c|c|c|c|c|c|}
\hline \multirow{2}{*}{ Instructo do pai } & \multicolumn{2}{|c|}{ Inscritos } & \multicolumn{2}{|c|}{ Aprovados } & \multirow{2}{*}{$\begin{array}{l}\text { Pereentual } \\
\text { Relativo }\end{array}$} \\
\hline & Total & $\%$ & Total & $\%$ & \\
\hline Nenhuma ou prim. incompleto & 698 & 27,12 & 198 & 24,32 & 28,37 \\
\hline Primário completo ou gin. incomp. & 820 & 31,86 & 242 & 29,72 & 29,51 \\
\hline Ginasial completo ou col. incomp. & 354 & 13,75 & 134 & 16,45 & 37,85 \\
\hline Coleginl completo ou sup. incomp. & 316 & 12,27 & 100 & 12,28 & 31,65 \\
\hline Superior completo & 385 & 14,96 & 140 & 17,19 & 36,36 \\
\hline
\end{tabular}

Fonte: Análise das informaçōes sócio-cducacionais - Vestibular 82 - Universidade do Rio Grande.

b) Universidade Federal de Santa Catarina - SC

Qual o nível de instrução do seu pai?

\begin{tabular}{|c|c|c|c|c|c|}
\hline \multirow{2}{*}{ Instruçto do pai } & \multicolumn{2}{|c|}{ Inscritos } & \multicolumn{2}{|c|}{ Aprovados } & \multirow{2}{*}{$\begin{array}{c}\text { Percentual } \\
\text { Relativo }\end{array}$} \\
\hline & Total & $\%$ & Total & $\%$ & \\
\hline Nenhuma ou prim. incompleto & 3.008 & 19,3 & 376 & 14,0 & 12,42 \\
\hline Primário completo ou gin. incomp. & 4.597 & 29,3 & 621 & 23,3 & 13,51 \\
\hline Ginasial completo ou col. incomp. & 1.692 & 10,7 & 278 & 10,4 & 16,43 \\
\hline Colegial completo ou sup, incomp. & 2.483 & 15,8 & 491 & 18,4 & 19,77 \\
\hline Superior completo & 3.108 & 19.8 & 799 & 29,9 & 25,71 \\
\hline
\end{tabular}

Fonte: Relatório - 1988/Universidade Federal de Santa Catarina 
c) Universidade Estadual Paulista - SP

Nível de instrução do pai

\begin{tabular}{l|c|c|c|c|c}
\hline \multirow{2}{*}{ Instruşlo do pai } & \multicolumn{2}{|c|}{ Inseritos } & \multicolumn{2}{c|}{ Aprovados } & \multirow{2}{*}{$\begin{array}{c}\text { Pereentual } \\
\text { Relativo }\end{array}$} \\
\cline { 2 - 5 } & Total & $\%$ & Total & $\%$ & \\
\hline Nenhuma ou primário completo & 4.348 & 13,71 & 636 & 17,43 & 14,63 \\
Primário completo ou gin. incomp. & $\mathbf{8 . 3 3 5}$ & 26,28 & 1.016 & 27,85 & 12,19 \\
Ginasial completo ou col. incomp. & 3.421 & 10,79 & 369 & 10,12 & 10,79 \\
Colegial completo ou sup. incomp. & $\mathbf{5 . 7 7 4}$ & 18,20 & 596 & 16,34 & 10,32 \\
Superior completo & $\mathbf{8 . 9 5 3}$ & 28,23 & 961 & 26,34 & $10,73$. \\
\hline
\end{tabular}

Fonte: Relatório Vestibular 87 - VUNESP

d) Universidade Federal do Rio de Janeiro - $R$

Nivel de instruçäo do pai

\begin{tabular}{|c|c|c|c|c|c|}
\hline \multirow{2}{*}{ Instrugalo do pai . } & \multicolumn{2}{|c|}{ Inscritos } & \multicolumn{2}{|c|}{ Aprovados } & \multirow{2}{*}{$\begin{array}{c}\text { Percentual } \\
\text { Relativo }\end{array}$} \\
\hline & Total & $\%$ & Total & $\%$ & \\
\hline Nenhuma ou primário incompleto & 3.960 & 14,56 & 174 & 6,19 & 4,39 \\
\hline Primário completo ou gin. incomp. & 3.408 & 19,52 & 357 & 12,69 & 6,60 \\
\hline Ginasial completo ou col. incomp. & 3.583 & 12,93 & 250 & 8,90 & 6,98 \\
\hline Colegial completo ou sup. incomp. & 5.650 & 20,39 & 564 & 20,06 & 9,98 \\
\hline Superior completo & 9.105 & 32,86 & 1.467 & $\mathbf{5 2 , 1 6}$ & 16,11 \\
\hline
\end{tabular}

"Essa variável impressiona. Mais da metade dos candidatos classificados säo alunos cujos pais têm instrução de nível superior completa."

Fonte: Perfil sócio-cultural dos candidatos classificados no concurso de seleçăo 88 UFRJ.

c) Universidade Federal de Pemambuco - PE

\begin{tabular}{|c|c|c|c|c|c|}
\hline \multirow{2}{*}{ Instrugto do pai } & \multicolumn{2}{|c|}{ Inscrilos } & \multicolumn{2}{|c|}{ Aprovados } & \multirow{2}{*}{$\begin{array}{l}\text { Percentual } \\
\text { Relativo }\end{array}$} \\
\hline & Total & $\%$ & Total & $\%$ & \\
\hline $\begin{array}{l}\text { Nenhuma ou primírio incompleto } \\
\text { Primário completo ou gin. incomp. } \\
\text { Ginasial completo ou col. incomp. } \\
\text { Colegial completo ou sup. incomp. } \\
\text { Superior completo }\end{array}$ & $\begin{array}{c}: \\
: \\
6.179\end{array}$ & $\dot{:}: \dot{ }$ & $\begin{array}{c}\ddot{*} \\
\dot{1} \\
1.593\end{array}$ & $\begin{array}{c}: \\
\dot{43,0}\end{array}$ & $\begin{array}{c}\bullet \\
\bullet \\
\bullet \\
25,78\end{array}$ \\
\hline
\end{tabular}

Fonte: Vestibular 89-Relatorio Analitico / COVEST - UFPE

"Dados năo disponíveis. 
f) Universidade Federal do Rio Grande do None - RGN

Qual o grau de instrução do seu pai?

\begin{tabular}{|c|c|c|c|c|c|}
\hline \multirow{2}{*}{ Instrupllo do pat } & \multicolumn{2}{|c|}{ Inscritos } & \multicolumn{2}{|c|}{ Aprovidos } & \multirow{2}{*}{$\begin{array}{c}\text { Percentual } \\
\text { Relativo }\end{array}$} \\
\hline & Total & $\%$ & Total & $\%$ & \\
\hline Nenhum & 2.377 & 14.59 & 128 & 7,13 & 5,30 \\
\hline Primário & B.453 & 51,91 & 715 & 39,87 & 8,40 \\
\hline Ginasło & 2.435 & 14,95 & 292 & 16,28 & 11,90 \\
\hline Colegial & 1.759 & 10,80 & 310 & 17,28 & 17,60 \\
\hline Superior & 1.236 & 7,59 & 345 & 19,24 & 24,90 \\
\hline
\end{tabular}
do pai."

"Os percentuais de desempenho crescem proporcionalmente com o grau de instrução

Fonte: Estudo analítico de dados sócio-cconômico-culturais dos candidatos ao concurso vestibular da UFRN - 1982.

g) Universidade Estadual do Ceand - CE

Nível de instruçäo do pai

\begin{tabular}{l|l|l|l|l|c}
\hline \multirow{2}{*}{ Instrujgto do pat } & \multicolumn{2}{|c|}{ Inseritos } & \multicolumn{2}{c|}{ Aprovidos } & $\begin{array}{c}\text { Percentual } \\
\text { Relativo }\end{array}$ \\
\cline { 2 - 5 } & Total & $\%$ & Total & $\%$ & \\
\hline Nenhuma ou primário incompleto & 2.634 & 30,0 & 586 & 21,3 & 22,24 \\
Primário completo ou gin. incomp. & 1.476 & 16,8 & 376 & 13,7 & 25,47 \\
Cinasial completo ou col. incomp. & 1.101 & 12,5 & 326 & 11,9 & 29,61 \\
Colegial completo ou sup. incomp. & 1.862 & 21,2 & 715 & 26,1 & 38,40 \\
Superior completo & 1.407 & 16,0 & 653 & 23,8 & 46,41 \\
\hline
\end{tabular}

Fonte: Perfil dos candidatos aos cursos da UECE - CEV/1988

h) Universidade de Fortaleza - $C E$

Nível de instrução do pai

\begin{tabular}{l|c|c|c|c|c}
\hline \multirow{2}{*}{ Insirueflo do pai } & \multicolumn{2}{|c|}{ Inscritos } & \multicolumn{2}{c|}{ Aprovados } & \multirow{2}{*}{$\begin{array}{c}\text { Pereentual } \\
\text { Relativo }\end{array}$} \\
\cline { 2 - 5 } & Total & $\%$ & Total & $\%$ & \\
\hline Nenhuma ou primário incompleto & 842 & 18 & 115 & 11 & 13,66 \\
Primário completo ou gin. incomp. & 729 & 16 & 117 & 11 & 16,05 \\
Ginasjal completo ou col. incomp. & 459 & 10 & 81 & 8 & 17,65 \\
Colegial completo ou sup. incomp. & 1.015 & 22 & 231 & 22 & 22,76 \\
Superior completo & 1.39 & 31 & 453 & 44 & 31,48 \\
\hline
\end{tabular}

"Em relaçâo aos aprovados, existe um forte predomínio dos candidatos fithos de pais com nivel superior completo, que representam perto de $50 \%$ dos aprovados. Apenas $13,66 \%$ dos filhos de pais sem nen/uma instruçâo foram classificados, enquanto $31,48 \%$ dos filhos de pais de nfvel superior completo foram aprovados no vestibular."

Fonte: O concurso vestibular na Universidade de Fortaleza - MAIO 89 
a) Fundaçäo Universidade do Rio Grande - RGS

Grau de escolaridade da måce

\begin{tabular}{l|l|l|c|c|c}
\hline \multirow{2}{*}{ Instrugå đa mate } & \multicolumn{2}{|c|}{ Inscritos } & \multicolumn{2}{c|}{ Aprovados } & \multirow{2}{*}{$\begin{array}{c}\text { Percentual } \\
\text { Relativo }\end{array}$} \\
\cline { 2 - 5 } & Total & $\%$ & Total & $\%$ & \\
\hline Nenhuma ou primário incompleto & 744 & 28,71 & 228 & 27,83 & 30,65 \\
Primário completo ou gin. incomp. & 912 & 35,21 & 262 & 31,98 & 28,73 \\
Ginasial completo ou col. incomp. & 352 & 13,58 & 117 & 14,27 & 33,24 \\
Colegial completo ou sup. incomp. & 345 & 13,31 & 129 & 15,74 & 37,39 \\
Superior completo & 237 & 9,15 & 83 & 10,13 & 35,02 \\
\hline
\end{tabular}

"O melhor desempenho na classe foi o daqueles cuja male possui curso superior incompleto."

Fonte: Análise das informaçōes sócio-econômicas -Vestibular 82-Universidade do Rio Grande.

b) Universidade Federal de Santa Catarina - SC

Qual o nfvel de instruçắo da sua mäe?

\begin{tabular}{l|l|l|l|l|l}
\hline \multirow{2}{*}{ Instruģto da mâe } & \multicolumn{2}{|c|}{ Inscritos } & \multicolumn{2}{c|}{ Aprovados } & \multirow{2}{*}{$\begin{array}{c}\text { Percentual } \\
\text { Relativo }\end{array}$} \\
\cline { 2 - 5 } & Total & $\%$ & Total & $\%$ & \\
\hline Nenhuma ou primário incompleto & 2.826 & 18,1 & 328 & 12,3 & 11,61 \\
Primário completo ou gin. incomp. & 5.037 & 32,1 & 694 & 26,0 & 13,78 \\
Ginasial completo ou col. incomp. & 2.251 & 14,3 & 416 & 15,6 & 18,48 \\
Colegial completo ou sup. incomp. & 3.144 & 20,0 & 707 & 26,5 & 22,49 \\
Superior completo & 1.804 & 11,5 & 438 & 16,4 & 24,28 \\
\hline
\end{tabular}

Fonte: Relatório vestibular - 1988/Universidade Federal de Santa Catarina.

c) Universidade Estadual Paulista - SP

Nivel de instruçảo da mãe

\begin{tabular}{l|l|l|r|r|r}
\hline \multirow{2}{*}{ Instruğto da mấc } & \multicolumn{2}{|c|}{ Inscritos } & \multicolumn{2}{c|}{ Aprovados } & \multirow{2}{*}{$\begin{array}{c}\text { Percentual } \\
\text { Relativo }\end{array}$} \\
\cline { 2 - 5 } & Total & $\%$ & Total & $\%$ & \\
\hline Nenhuma ou primário incompleto & 4.227 & 13,33 & 609 & 16,69 & 14,41 \\
Primáríto completo ou gin. incomp. & 9.603 & 30,28 & 1.229 & 33,69 & 12,80 \\
Ginasial completo ou col. incomp. & 4.133 & 13,03 & 426 & 11,68 & 10,31 \\
Colegial completo ou sup. incomp. & 6.390 & 20,15 & 628 & 17,22 & 9,83 \\
Superior completo & 6.536 & 20,61 & 688 & 18,86 & 10,53 \\
\hline
\end{tabular}

Fonte: Relatório Vestibular 87 - VUNESP 
d) Universidade Federal do Rio de Janeiro - $R J$

Nivel de instrução da mấe

\begin{tabular}{l|c|c|c|c|c}
\hline \multirow{2}{*}{ Instrugäo da mac } & \multicolumn{2}{|c|}{ Inscrilos } & \multicolumn{2}{c|}{ Aprovados } & \multicolumn{2}{c}{$\begin{array}{c}\text { Pereentual } \\
\text { Relativo }\end{array}$} \\
\cline { 2 - 5 } & Total & $\%$ & Total & $\%$ & \\
\hline Nenhuma ou primário incompleto & 4.297 & 15,51 & 17 & 6,13 & 4,00 \\
Primário completo ou gin. incomp. & 6527 & 23,56 & 443 & 15,77 & 6,79 \\
Ginasial completo ou col. incomp. & 4.722 & 17,04 & 393 & 13,96 & 8,32 \\
Colcgial completo ou sup. incomp. & 6.948 & 25,08 & 909 & 32,33 & 13,08 \\
Superior completo & 5.212 & 18,81 & 895 & 31,81 & 17,17 \\
\hline
\end{tabular}

Fonte: Perfil sócio-cultural dos candidatos classificados no concurso de seleçåo 88/UFRJ

c) Universidade Federal de Pernambuco - PE

\begin{tabular}{|c|c|c|c|c|c|}
\hline \multirow{2}{*}{ Instructo da mac } & \multicolumn{2}{|c|}{ Inscritos } & \multicolumn{2}{|c|}{ Aprovados } & \multirow{2}{*}{$\begin{array}{l}\text { Percentual } \\
\text { Relativo }\end{array}$} \\
\hline & Total & $\%$ & Total & $\%$ & \\
\hline $\begin{array}{l}\text { Nenhuma ou primário incompleto } \\
\text { Primário completo ou gin. incomp. } \\
\text { Ginasial completo ou col. incomp. } \\
\text { Colegial completo ou sup. incomp. } \\
\text { Superiot completo }\end{array}$ & $\begin{array}{l}: \\
: \\
4.818\end{array}$ & $\begin{array}{l}\dot{*} \\
\dot{2} \\
\dot{2}\end{array}$ & $\stackrel{\bullet}{:}$ & $\dot{:}:$ & $\stackrel{\bullet}{*} \cdot \overrightarrow{2}$ \\
\hline
\end{tabular}

Fonte: Vestibular 89 - Relatório Analítico / COVEST - UFPE

"Dados não disponíveis.

f) Universidade Federal do Rio Grande do Norte - RGN

Qual o grau de instruçâo de sua mãe?

\begin{tabular}{|c|c|c|c|c|c|}
\hline \multirow{2}{*}{ Instruğăo da mấe } & \multicolumn{2}{|c|}{ Inscritos } & \multicolumn{2}{|c|}{ Aprovados } & \multirow{2}{*}{$\begin{array}{l}\text { Percentual } \\
\text { Relativo }\end{array}$} \\
\hline & Total & $\%$ & Total & $\%$ & \\
\hline Nenhuma ou primário incompleto & 1.794 & 11,01 & 95 & 5,29 & 5,20 \\
\hline Primário completo ou gin. incomp, & 9.041 & 55,52 & 756 & 42,16 & 8,30 \\
\hline Ginesial completo ou col. incomp. & 3.022 & 18,56 & 388 & 21,63 & 12,80 \\
\hline Coleglal completo ou sup, incomp. & 1.759 & 10,80 & 361 & 20,13 & 20,50 \\
\hline Superior completo & 646 & 3,96 & 189 & 10,54 & 29,20 \\
\hline
\end{tabular}

"Esta questão parece evidenciar a tese de que a convivência com pessoas de maior grau de instruçdo é importante para classificaçäo no vestibular."

Fonte: Estudo analítico de dados sócio-econômico-culturais dos candidatos ao concurso vestibular da UFRN - 1982. 
g) Universidade Estadual do Ceara - CE

Nfvel de instruçăo da mảe

\begin{tabular}{l|c|c|c|c|c}
\hline \multirow{2}{*}{ Instruçlo da mâle } & \multicolumn{2}{|c|}{ Inscrilos } & \multicolumn{2}{c|}{ Aprovados } & \multirow{2}{*}{$\begin{array}{c}\text { Percentual } \\
\text { Relativo }\end{array}$} \\
\cline { 2 - 5 } & Total & $\%$ & Total & $\%$ & \\
\hline Nenhuma ou primário incompleto & 2.169 & 24,7 & 477 & 17,5 & 21,99 \\
Primírio completo ou gin. incomp. & 1.662 & 18,9 & 410 & 15,0 & 24,67 \\
Ginasial completo ou col. incomp. & 1.384 & 15,8 & 432 & 15,8 & 31,21 \\
Colegial completo ou sup. incomp. & $\mathbf{2 . 2 7 8}$ & 26,0 & 884 & 32,3 & 38,81 \\
Superior completo & $1: 034$ & 11,8 & 459 & 16,8 & 44,39 \\
\hline
\end{tabular}

Fonte: Perfil dos candidatos aos cursos da UECE - CEV / 1988

h) Universidade de Fortaleza - CE

Nivel de instruçăo da măe

\begin{tabular}{l|r|r|r|r|c}
\hline \multirow{2}{*}{ Instruģto da mfie } & \multicolumn{2}{|c|}{ Inscritos } & \multicolumn{2}{c|}{ Aprovados } & \multirow{2}{*}{$\begin{array}{c}\text { Percentual } \\
\text { Relativo }\end{array}$} \\
\cline { 2 - 5 } & Total & $\%$ & Total & $\%$ & \\
\hline Nenhuma ou primário incompleto & 658 & 14 & 76 & 7 & 11,55 \\
Primário completo ou gin. incomp. & 857 & 18 & 140 & 14 & 16,34 \\
Ginasial completo ou col. incomp. & 595 & 13 & 102 & 10 & 17,14 \\
Colegial completo ou sup. incomp. & 1.450 & 31 & 394 & 38 & 27,17 \\
Superior completo & 951 & 20 & 288 & 28 & 30,28 \\
\hline
\end{tabular}

"Os filhos de males de baixa instruçäo classificaram somente $11,55 \%$ dos seus candidatos, para uma aprovaçáo de $30,28 \%$ dos filhos de mäes de nfvel superior."

Fonte: $\mathrm{O}$ concurso vestibular na Universidade de Fortaleza - MAIO/89.

Algumas conclusōes podem ser tiradas quanto a influencia da escolaridade dos pais:

a) observa-se um equilibrio na distribuiçāo dos candidatos inscritos em relaçăo ao nfvel de instruçäo do pai em todas as Universidades analisadas;

b) em relaçăo aos candidatos aprovados existe um forte predomínio dos candidatos filhos de pais com niveis mais alto de instruçăo, que representam em muitos casos mais de $50 \%$ dos classificados;

c) pequenas percentagens de filhos de pais sem instruçăo foram aprovados, enquanto expressivos valores percentuais de filhos de pais de nivel superior consegucm aprovaçăo;

d) novamente a UNESP-SP apresenta valores percentuais destoantes da maioria nacional, o que reforça a crença de que no Estado de São Paulo o ensino 6 mais aproveitado; 
e) nota-se uma influência menor do grau de escolaridade da mãe na aprovaçăo dos candidatos, mas expressivos valores são verificados para os filhos de mães de melhor instrução;

I) em todas as Universidades observa-se um melhor desempenho dos filhos de mäes de maior escolaridade em relaçäo aos filhos de mảes de baixa instruçăo.

\subsection{Ocupaçio principal do pai}

As diversas ocupaçōes possfveis foram agrupadas de maneira diferente em cada uma das Universidadc, mas este fato nāo invalida a possibilidade de uma análise conjunta destes dados.

a) Universidade Federal de Santa Catarina -SC

Qual a ocupaçåo principal de seu pai ou responsável?

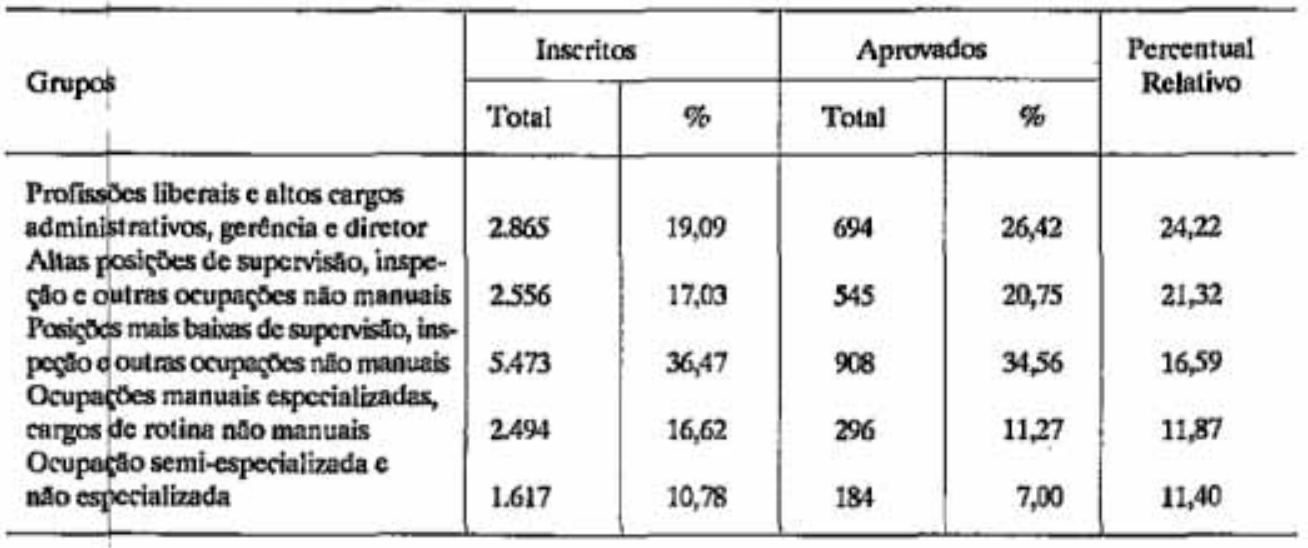

Fonte: Relatório Vestibular 1988/UFSC

b) Universidade Estadual Paulista - SP

Ocupaçăo principal do pai ou responsável?

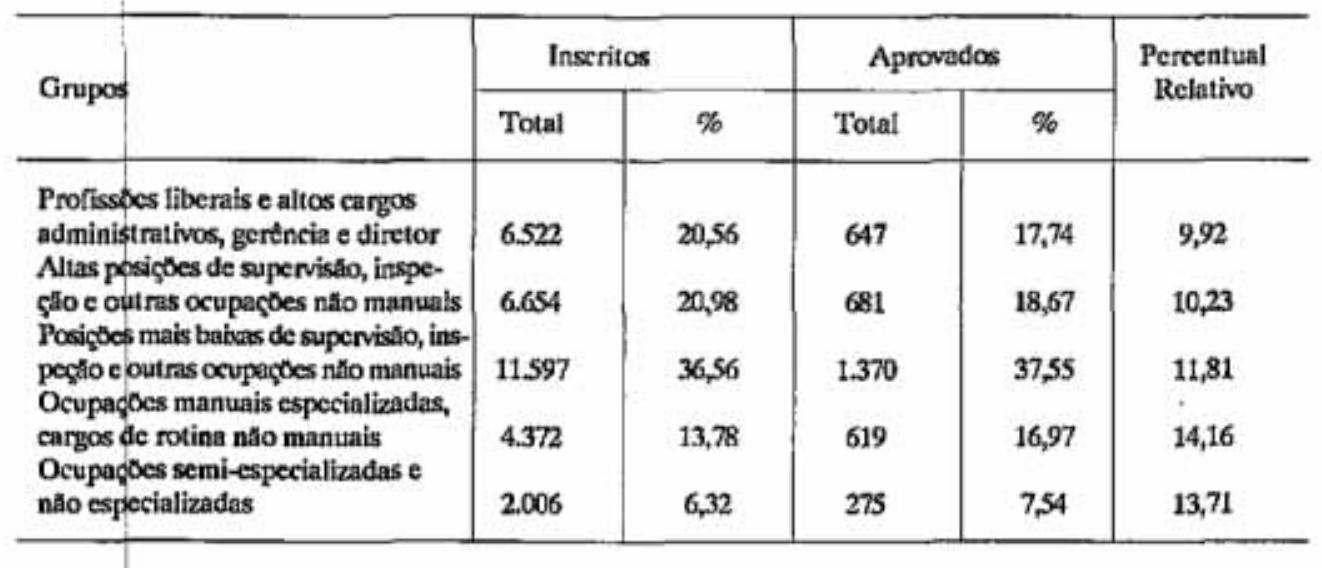

Fonte: Relatório Vestibular 87 - VUNESP 
c) Universidade Federal do Rio de Janeiro - $R J$

Ocupaçâo principal do pai

\begin{tabular}{|c|c|c|c|c|c|}
\hline \multirow{2}{*}{ Aliemativas } & \multicolumn{2}{|c|}{ Inscritos } & \multicolumn{2}{|c|}{ Aprovados } & \multirow{2}{*}{$\begin{array}{c}\text { Percentual } \\
\text { Relativo }\end{array}$} \\
\hline & Total & $\%$ & Total & $\%$ & \\
\hline $\begin{array}{l}\text { Industrial, banqueiros, incorpo- } \\
\text { rador } \\
\text { Proprietário na agricultura, no co- } \\
\text { mércio e nos serviços de aloja- } \\
\text { mento } \\
\text { Diretor, administrador ou gerente } \\
\text { Oeupeço de nfvel superior } \\
\text { Militar oficial }\end{array}$ & $\begin{array}{l}1.165 \\
3.385 \\
3.167 \\
6.444 \\
1.583\end{array}$ & $\begin{array}{r}4,20 \\
12,22 \\
11,43 \\
23,26 \\
5,71\end{array}$ & $\begin{array}{r}115 \\
\\
350 \\
384 \\
1.045 \\
189\end{array}$ & $\begin{array}{r}4,08 \\
12,46 \\
13,66 \\
37,14 \\
6,72\end{array}$ & 13,23 \\
\hline $\begin{array}{l}\text { Militar nâo oficial } \\
\text { Ocupaçlo de nfvel međito }\end{array}$ & $\begin{array}{l}1.557 \\
4.698\end{array}$ & $\begin{array}{r}5,62 \\
16,96\end{array}$ & $\begin{array}{r}78 \\
401\end{array}$ & $\begin{array}{r}2,78 \\
14,27\end{array}$ & 7,66 \\
\hline $\begin{array}{l}\text { Ocupaçato manual nos servisos e no } \\
\text { comércio } \\
\text { Trabalhador manual na agricultura }\end{array}$ & $\begin{array}{r}5.327 \\
380\end{array}$ & $\begin{array}{r}19,23 \\
1,37\end{array}$ & $\begin{array}{r}236 \\
14\end{array}$ & $\begin{array}{l}8,38 \\
0,51\end{array}$ & 4,38 \\
\hline
\end{tabular}

Fonte: Perfil sócio-cultural dos candidatos classificados no concurso de seleçåo 88/UFRJ.

d) Universidade Federal de Pernambuco - PE

Formaçẩo dos pais

\begin{tabular}{|c|c|c|c|c|c|}
\hline \multirow{2}{*}{ Alternativas } & \multicolumn{2}{|c|}{ Inscritos } & \multicolumn{2}{|c|}{ Aprovados } & \multirow{2}{*}{$\begin{array}{l}\text { Percentual } \\
\text { Relativo }\end{array}$} \\
\hline & Total & $\%$ & Total & $\%$ & \\
\hline Pai universitário & 6.179 & 29,5 & 1.593 & 43,0 & 25,78 \\
\hline Pai nllo universitárto & 14.767 & 70,5 & 2.112 & 57,0 & 14,30 \\
\hline Male universitaria & 4.818 & 23,0 & 1.297 & 35,0 & 26,92 \\
\hline Măc năo universitíria & 16.128 & 77,0 & 2.408 & 65,0 & 14,93 \\
\hline
\end{tabular}

Fonte: Relatório análitico - Vestibular 89 - COVEST/UFPE 
e) Universidade Federal do Rio Grande do Norte - RGN

Qual das categorias melhor descreve a ocupaçāo do seu pai?

\begin{tabular}{|c|c|c|c|c|c|}
\hline \multirow{2}{*}{ Alternativas } & \multicolumn{2}{|c|}{ Inscritos } & \multicolumn{2}{|c|}{ Aprovados } & \multirow{2}{*}{$\begin{array}{c}\text { Percentual } \\
\text { Relativo }\end{array}$} \\
\hline & Total & $\%$ & Total & $\%$ & \\
\hline Magistérto & 220 & 1,35 & 45 & 2,50 & 20,40 \\
\hline Prolissionat liberal & 836 & 5,13 & 136 & 7,58 & 16,20 \\
\hline Diretor de empresa & 221 & 1,35 & 42 & 2,34 & 19,00 \\
\hline Comereiante & 2.932 & 17,95 & 360 & 20,07 & 12,30 \\
\hline Militar & 1.390 & 8,53 & 210 & 11,71 & 15,10 \\
\hline Funcionário Público & 3.205 & 19,68 & 387 & 21,58 & 12,00 \\
\hline Propriatário de Fazenda & 779 & 4,78 & 68 & 3,79 & 8,70 \\
\hline Agricultor & 2.535 & 15,56 & 131 & 7,30 & 5,10 \\
\hline Ocupação técnica (vendedor, baned- & & & & & \\
\hline rio, secretário) & 371 & 2,27 & 67 & 3,73 & 18,00 \\
\hline Ocupaçūo manual especializada & 1.581 & 9,71 & 134 & 7,47 & 8,40 \\
\hline Ocupaçfo manual nato especializada & 204 & 1,25 & 30 & 1,67 & 14,70 \\
\hline Outras & 1.846 & 11,33 & 173 & 9,64 & 9,30 \\
\hline Desempregado & 111 & 0,68 & 4 & 0,22 & 3,60 \\
\hline
\end{tabular}

Fonte: Estudo analítico de dados sócio-econômico-culturais dos candidatos ao concurso vestibular da UFRN - 1982

f) Universidade Estadual do Ceará - CE

Ocupaçăo principal do pai.

\begin{tabular}{|c|c|c|c|c|c|}
\hline \multirow{2}{*}{ Ocupagato do pait } & \multicolumn{2}{|c|}{ Inscritos } & \multicolumn{2}{|c|}{ Aprovados } & \multirow{2}{*}{$\begin{array}{c}\text { Percentual } \\
\text { Relativo }\end{array}$} \\
\hline & Total & $\%$ & Total & $\%$ & \\
\hline $\begin{array}{l}\text { Prolissional liberal e téc. de nf- } \\
\text { vel superior }\end{array}$ & 983 & 11,3 & 436 & 15,9 & 44,35 \\
\hline $\begin{array}{l}\text { Propriatário e administrador de } \\
\text { grande empresa }\end{array}$ & 257 & 2,9 & 78 & 2,8 & 30,35 \\
\hline Proprictário de média empresa & 936 & 10,7 & 292 & 10,7 & 31,20 \\
\hline Proprictário de pequena empresa & 1.571 & 18,0 & 475 & $17, A$ & 30,24 \\
\hline Professor de $1^{2}$ ou de $2^{\circ} \mathrm{grau}$ & 164 & 1,9 & 52 & 1,9 & 31,70 \\
\hline Ocupagto no setor primário & 491 & 5,6 & 97 & 3,6 & 19,76 \\
\hline Ocupacto no setor secundário & 744 & 8,5 & 178 & 6,5 & 23,92 \\
\hline Ocupaçlo no setor tercírí & 2882 & 33,0 & 915 & 33,5 & 31,75 \\
\hline Vive de renda & 86 & 1,0 & 10 & 0,4 & 11,62 \\
\hline Desempregado & 22 & 0,2 & 6 & 0,2 & 27,27 \\
\hline
\end{tabular}

Fonte: Perfil dos candidatos aos cursos da UECE - CEV/1988 
g) Universidade de Fortaleza - CE

Ocupação principal do pai

\begin{tabular}{|c|c|c|c|c|c|c|}
\hline \multirow{2}{*}{ Nivel } & \multirow{2}{*}{ Ocupaçato do pail } & \multicolumn{2}{|c|}{ Inseritos } & \multicolumn{2}{|c|}{ Aprovados } & \multirow{2}{*}{$\begin{array}{c}\text { Percentual } \\
\text { Relativo }\end{array}$} \\
\hline & & Total & $\%$ & Total & $\%$ & \\
\hline 1 & $\begin{array}{l}\text { Proprietdrios e adm. đe } \\
\text { grandes empresas } \\
\text { Profissionais tiberais e } \\
\text { técnieos de nível superior } \\
\text { Proprietários de médias } \\
\text { empresas } \\
\text { Administradores } \\
\text { Militares ofteiais }\end{array}$ & $\begin{array}{l}276 \\
982 \\
642 \\
541 \\
142\end{array}$ & $\begin{array}{r}6 \\
21 \\
14 \\
12 \\
3\end{array}$ & $\begin{array}{r}59 \\
302 \\
126 \\
132 \\
30\end{array}$ & $\begin{array}{r}6 \\
29 \\
12 \\
13 \\
3\end{array}$ & . \\
\hline Total & & 2.583 & 56 & 649 & 63 & 25,13 \\
\hline 2 & $\begin{array}{l}\text { Profissionais e tecniecs } \\
\text { de nível medio } \\
\text { Proprietários de pequenas } \\
\text { empresas } \\
\text { Professores secundários e } \\
\text { tec. e adm. do setor pri- } \\
\text { mário } \\
\text { Tlenicos e auxiliares } \\
\text { Militares nalo oficiais e } \\
\text { atletas profissionais }\end{array}$ & $\begin{array}{r}93 \\
168 \\
63\end{array}$ & $\begin{array}{r}6 \\
13\end{array}$ & $\begin{array}{l}66 \\
123\end{array}$ & $\begin{array}{r}6 \\
12\end{array}$ & \\
\hline Total & & 1.245 & 26 & 257 & 25 & 20,64 \\
\hline & $\begin{array}{l}\text { Professores primários e } \\
\text { afins } \\
\text { Oeupacoes de escritorio } \\
\text { Mestres, contramestres e } \\
\text { ocupaçes na ind. mecánica } \\
\text { Oeupacoes de transporte e: } \\
\text { comunicaçes } \\
\text { Trabalhadores na constru- } \\
\text { glo e assemelhados }\end{array}$ & $\begin{array}{r}50 \\
85 \\
135 \\
146 \\
377\end{array}$ & $\begin{array}{l}1 \\
2 \\
3 \\
3 \\
8\end{array}$ & $\begin{array}{l}12 \\
17 \\
20 \\
27 \\
43\end{array}$ & $\begin{array}{l}1 \\
2 \\
2 \\
3 \\
4\end{array}$ & \\
\hline Total & & 793 & 17 & 119 & 12 & 15,01 \\
\hline
\end{tabular}

Fonte: O vestibular na Universidade de Fortaleza - MAIO 89

O nfvel em que se situa a ocupaçäo do pai do candidato tem uma grande influência na possibilidade de aprovaçäo no concurso vestibular. Sobre esta influência podemos fazer os comentários:

a) percebe-se claramente o predomf́nio das classes alta $\mathrm{e}$ média em relaçăo às classes menos privilegiadas já na inscriçăo dos candidatos;

b) após o concurso verificamos que as maiores percentagens de ocupação das vagas estão nas categorias de maior nfvel de status;

c) em relaçăo ao percentual relativo, observa-se que o desempenho dos candidatos cujos pais exercem ocupaçōes mais importantes é sempre bem melhor do que 
aquele dos filhos de pais de profissöes mais simples;

d) mais umaveza UNESP-SP apresentou um resultadodiscrepanteem relaçăoàs demais;

e) esta influĉncia é uma conseqüência direta do nivel de vida dos diversos estratos sociais, onde, cvidentemente, os filhos das famflias das classes mais altas dispổem de melhores colégios, professores particulares, livros a vontade, ambiente apropriado para o estudo e, às vezes, até carro próprio;

f) ao contrário, aqueles que vêm de classes mais baixas, enfrentam difículdades de toda ordem, do transporte à alimentação, passando por todos os outros problemas próprios da pobreza.

\subsection{Renda familiar}

Como no item anterior, os limites de renda foram diferentes, mas este fato nāo invalida a análise conjunta dos dados estatísticos adotados.

a) Fundação Universidade do Rio Grande - RS

Renda familiar mensal

\begin{tabular}{l|r|r|r|r|c}
\hline \multirow{2}{*}{$\begin{array}{l}\text { Renda mensal do paf } \\
\text { ou da familia }\end{array}$} & \multicolumn{2}{|c|}{ Inseritos } & \multicolumn{2}{c|}{ Aprovados } & \multirow{2}{*}{$\begin{array}{c}\text { Percentual } \\
\text { Relativo }\end{array}$} \\
\cline { 2 - 5 } & Total & $\%$ & Total & $\%$ & \\
\hline Menos de 1 SM & 29 & 1,12 & 10 & 1,22 & 34,40 \\
De 1 a 3 SM & 574 & 22,18 & 164 & 20,09 & 28,57 \\
Mais de 3 ate 5 SM & 694 & 26,82 & 213 & 26,10 & 30,69 \\
Mais de 5 ate 10 SM & 701 & 27,09 & 222 & 27,20 & 31,66 \\
Mais de 10 SM & 589 & 22,76 & 207 & 25,36 & 35,15 \\
\hline
\end{tabular}

"É na última faixa que se concentra o maior percentual de aprovados. Analisando a aprovação em cada curso, percebe-se que nos cursos onde houve maior disputa candidatos/vaga e aprovaçäo concentra-se ainda mais nos que possuem renda familiarmais elevada: Mediciñ $(42 \%)$ e Oceanologia (51\%)."

Fonte: Análise das informaçōes sócio-educacionais - Vestibular 82 - Universidade do Rio Grande.

b) Universidade Federal de Santa Catarina - SC

Qual a renda total de sua família?

\begin{tabular}{l|c|c|c|c|c}
\hline \multirow{2}{*}{$\begin{array}{l}\text { Renda mensal do pai } \\
\text { ou da familia }\end{array}$} & \multicolumn{2}{|c|}{ Inscritos } & \multicolumn{2}{c|}{ Aprovados } & \multirow{2}{*}{$\begin{array}{c}\text { Percentual } \\
\text { Relativo }\end{array}$} \\
\cline { 2 - 5 } & Total & $\%$ & Total & $\%$ & \\
\hline Menos de 1 SM & 73 & 0,5 & 17 & 0,6 & 23,29 \\
De 1 a 4 SM & 1.369 & 8,6 & 148 & 5,5 & 10,81 \\
Mais de 4 ate 7 SM & 2.674 & 17,1 & 356 & 13,3 & 13,20 \\
Mais de 7 ate 11 SM & 4.213 & 26,9 & 601 & 22,5 & 14,27 \\
Mais de 11 SM & 7.015 & 44,7 & 1.511 & 56,6 & 21,54 \\
\hline
\end{tabular}

Fonte:

Relatório vestibular - 1988/Universidade Federal de Santa Catarina 
c) Fundaçäo Estadual Paulista - SP

Renda mensal familiar

\begin{tabular}{|c|c|c|c|c|c|}
\hline \multirow{2}{*}{$\begin{array}{l}\text { Renda mensal do pai } \\
\text { ou da familia }\end{array}$} & \multicolumn{2}{|c|}{ Inseritos } & \multicolumn{2}{|c|}{ Aprovados } & \multirow{2}{*}{$\begin{array}{l}\text { Percentua } \\
\text { Relativo }\end{array}$} \\
\hline & Total & \% & Total & $\%$ & \\
\hline Ale Cos $4.000,00$ & 2885 & 9,10 & 469 & 12,86 & 16,22 \\
\hline $\mathrm{De} \operatorname{C} 2 \$ 4.000,00$ a C2 $\$ 8,400,00$ & 6.658 & 20,99 & 906 & 24,84 & 13,61 \\
\hline Mais de $C>\$ 8.400,00$ até $C \not \$ 11.700$ & 5,496 & 17,33 & 654 & 17,93 & 11,90 \\
\hline Mais de C2S 11.700 ates C2\$ 16.000 & 4.798 & 15,13 & 551 & 15,10 & 11,48 \\
\hline Mais de C2\$ 16.000 ate CZ\$ 20.000 & 3.716 & 11,72 & 372 & 10,20 & 10,01 \\
\hline Mais de C2\$ 20.000 ate C2\$ 31.600 & 4.412 & 13,91 & 408 & 11,18 & 9,25 \\
\hline Mais de C2\$31.600 & 3.195 & 10,07 & 239 & 6,55 & 7,48 \\
\hline
\end{tabular}

Fonte: Relatório Vestibular 87 - VUNESP

d) Universidade Federal do Rio de Janeiro - $R J$

Renda mensal total da famflia

\begin{tabular}{|c|c|c|c|c|c|}
\hline \multirow{2}{*}{$\begin{array}{l}\text { Renda mensal do pai } \\
\text { ou da famnlia }\end{array}$} & \multicolumn{2}{|c|}{ Inscritos } & \multicolumn{2}{|c|}{ Aprovados } & \multirow{2}{*}{$\begin{array}{c}\text { Percentual } \\
\text { Relativo }\end{array}$} \\
\hline & Total & $\%$ & Total & $\%$ & \\
\hline Até C2\$3.000 & 1.052 & 3,80 & 64 & 2,28 & 6,08 \\
\hline Mais de CZS 3.000 ate CZS 7.000 & 2842 & 10,26 & 136 & 4,84 & 4,79 \\
\hline Mais de CXS 7.000 ale C2S 10.000 & 3.928 & 14,18 & 211 & 7,50 & 5,37 \\
\hline Mais de C.\$ 10.000 até C2\$ 20.000 & 6.200 & 22,38 & 487 & 17,32 & 7,85 \\
\hline Mais de CzS20,000 ate CzS 30.000 & 4.745 & 17,13 & 530 & 18,85 & 11,17 \\
\hline Mais de C.S 30.000 até C.2\$ 50.000 & 4.000 & 14,44 & SSO & 19,56 & 13,75 \\
\hline Mais de C.\$ 50.000 ate C2\$ 70.000 & 2.232 & 8,06 & 367 & 13,05 & 16,44 \\
\hline Mais de C. $\$ 70.000$ & 2707 & 9,77 & 457 & 16,61 & 17,25 \\
\hline
\end{tabular}

"Salário minimo na época da inscriçäa: Cz\$1.969,62.

Quanto maior a nenda familiar, maior a proporstäo de ahmos classificados no concurso."

Fonte: Perfil sócio-cultural dos candidatos classificados no concurso de seleçăo 88/UFRJ.

c) Universidade Federal de Pernambuco - PE

Renda familiar

\begin{tabular}{l|c|c|c|c|c}
\hline \multirow{2}{*}{$\begin{array}{l}\text { Rendam mensal do pai } \\
\text { Ou da familia }\end{array}$} & \multicolumn{2}{|c|}{ Inscritos } & \multicolumn{2}{c|}{ Aprovados } & \multirow{2}{*}{$\begin{array}{c}\text { Percentual } \\
\text { Relativo }\end{array}$} \\
\cline { 2 - 5 } & Total & $\%$ & Total & $\%$ & \\
\hline Menor de 5 SM & 6.493 & 31 & 778 & 21 & 11,98 \\
Entre 10 e 20 SM & 3.560 & 17 & 778 & 21 & 21,85 \\
Maior de 20 SM & 4.189 & 20 & 1.112 & 30 & 26,55 \\
\hline
\end{tabular}

"O vestibular põe à mostra a forte correlaçđo que existe entre o nivel de renda $e$ desempenino acadêmico da populaçäo, em funçăo da fragilidade da estuntura de ensino público de $1^{\circ} e 2^{e}$ grants."

Fonte: Vestibular 89 - Relatório Analítico / COVEST-UFPE 
f) Universidade Federal do Rio Grande do Norte - RGN

Qual a renda da familia?

\begin{tabular}{l|r|r|r|r|c}
\hline \multirow{2}{*}{$\begin{array}{l}\text { Renda mensal do pai } \\
\text { ou da familia }\end{array}$} & \multicolumn{2}{|c|}{ Inscritos } & \multicolumn{2}{c|}{ Aprovados } & \multirow{2}{*}{$\begin{array}{c}\text { Perentual } \\
\text { Relativo }\end{array}$} \\
\cline { 2 - 5 } & Total & $\%$ & Total & $\%$ & \\
\hline Menos đe 1 SM & 230 & 1,41 & 45 & 2,50 & 19,57 \\
De 1 a 3 SM & 1.099 & 6,74 & 182 & 10,14 & 16,56 \\
Mais de 3 at6 S SM & 4.317 & 26,51 & 570 & 31,78 & 13,20 \\
Mais de 5 at6 10 SM & 8.475 & 52,03 & 789 & 43,98 & 9,31 \\
Mais de 10 SM & 2.161 & 12,58 & 207 & 11,53 & 9,58 \\
\hline
\end{tabular}

"Permance a indagaşão sobre a fidedignidade das informaç̧ठes quando se consideram os partametros onde o maior número de classificados esta na faixa de menor renda."

Fonte: Estudo analítico de dados sócio-econômico- culturais dos candidatos ao concurso vestibular da UFRN - 1982.

g) Universidade Estadual do Ceará - $C E$

Renda mensal do pai

\begin{tabular}{l|r|r|r|r|c}
\hline \multirow{2}{*}{$\begin{array}{l}\text { Renda mensal do pai } \\
\text { ou da famflia }\end{array}$} & \multicolumn{2}{|c|}{ Inseritos } & \multicolumn{2}{c|}{ Aprovados } & \multirow{2}{*}{$\begin{array}{c}\text { Perentual } \\
\text { Relativo }\end{array}$} \\
\cline { 2 - 5 } & Total & $\%$ & Total & $\%$ & \\
\hline Atế 1 SM & 506 & 5,8 & 81 & 3,0 & 16,01 \\
De 1 a 3 SM & 1.622 & 18,6 & 360 & 13,2 & 22,19 \\
Mais de 3 até 6 SM & 1.803 & 20,7 & 568 & 20,9 & 31,50 \\
Mais de 6 até 10 SM & 1.576 & 18,1 & 533 & 19,6 & 33,82 \\
Mais de 10 até 20 SM & 1.311 & 15,0 & 507 & 18,6 & 38,67 \\
Acima đe 20 SM & 1.224 & 14,0 & 516 & 19,0 & 42,16 \\
\hline
\end{tabular}

Fonte: Perfil dos candidatos aos cursos da UECE - CEV/1988

b) Universidade de Fortaleza - CE

Renda mensal do pai

\begin{tabular}{|c|c|c|c|c|c|}
\hline \multirow{2}{*}{$\begin{array}{l}\text { Renda mensal do pai } \\
\text { ou da familia }\end{array}$} & \multicolumn{2}{|c|}{ Inscritos } & \multicolumn{2}{|c|}{ Aprovados } & \multirow{2}{*}{$\begin{array}{c}\text { Percentual } \\
\text { Relativo }\end{array}$} \\
\hline & Total & $\%$ & Total & $\%$ & \\
\hline Alć $1 \mathrm{SM}$ & 255 & 5,43 & 32 & 3,07 & 12,55 \\
\hline De 1 a 3 SM & 570 & 12,14 & 81 & 7,79 & 14,21 \\
\hline Mais de 3 atć $6 \mathrm{SM}$ & 786 & 16,74 & 163 & 15,68 & 20,74 \\
\hline Mais de 6 ate 10 SM & 841 & 17,92 & 184 & 17,70 & 21,88 \\
\hline Mais đe 10 até $20 \mathrm{SM}$ & 855 & 18,21 & 219 & 21,07 & 25,61 \\
\hline Acima de $20 \mathrm{SM}$ & 1.244 & 26,50 & 331 & 31,85 & 26,61 \\
\hline
\end{tabular}

"Nota-se um pior desempenho no concurso das faixas de menores renda, o que $\varepsilon^{-}$ ressaltado pelos maiores tndices de aprovação com o crescimento dos salários."

Fonte: O concurso vestibular na Universidade de Fortaleza - MAIO 89. 
Há uma irrefutável correspondência entre a renda familiar mensal do candidato c o seu desempenho no concurso vestibular, o que é mostrado em números nos quadros apresentados e nos comentários a seguir:

a) a distribuiçäo dos inscritos no concurso $\mathrm{em}$ funçäo da renda familiar do candidato mostra um crescimento no mesmo sentido do aumento dos salários, o que indica uma seleção prévia já na inscriçâo do concurso, onde os de menor renda candidatam-se menos;

b) este fato, já observado em outros comentários anteriores, indica que a distribuiçăo dos inscritos nas diversas faixas de renda $c$ o inverso da realidade da renda da populaçäo como um todo;

c) nota-se um pior desempenho no concurso das faixas de mais baixa renda, o que é destacado pelos maiores indices de aprovação com o orescimento dos salários.

\section{CONCLUSÃo}

\subsection{Comentários finais}

O panorama observado na problemática do acesso à Universidade brasileira apresenta-se condicionado, marcantemente, por alguns fatores limitantes que tendem a tornar cada vez mais traumática a transiçăo entre os niveis de ensino secundário e superior. Estes aspectos, que foram observados ao longo deste estudo, embora não possam sofrer uma generalizaçāo, dada a precariedade dos dados disponiveis de apenas oito instituições, certamente não estăo muito afastados de uma afirmaçảo incontestável. $\mathrm{Na}$ verdade, nenhum estudo de cunho rigorosamente cientifico foi fcito até agora para verificar as reais influências das variáveis sócio-econômicas nos resultados do exame de seleçăo para acesso a Universidade. Apesar disso, porem, podemos observar que determinados fatores podem ser considerados como influenciadores deste processo de seleção existente à entrada da Universidade.

O atual quadro existente às portas da Universidade Brasileira tem-se caracterizado pelas seguintes condiçōes:

a) poucas vagas disponíveis nos cursos de graduação das IES do pafs em relação ao número de candidatos que pleiteiam o ensino superior, o que coloca fora da Universidade grandes contingentes de egresssos do $2^{\circ}$ grau. Estima-se que nestc ano de 1989 cerca de 2 milhōes de jovens foram impedidos de chegar à educaçäo superior;

b) discriminaçâo no acesso à Universidade em função de fatores sócio-econômicos, o que é observado largamente nos relatórios comentados e onde se verifica que têm mais chance de aprovaçâo os alunos de escolas particulares, os que estudam durante o dia, os filhos de pais de nfvel superior, aqueles que compōem famílias de elevada renda ou de ocupantes de funçōes destacadas na hierarquia profissional. Esta discriminaçäo assume aspectos ainda mais graves na escolha dos cursos quando aqueles socialmente bem situados ocupam quase que totalmente o espaço dos cursos de prestígio, enquanto que para os dependentes 
de famflia de baixa renda sobram os cursos de baixa procura c pouco mercado de trabalho. Recente pesquisa efetuada com os matriculados no primeiro semestre da USP diagnosticou que, no curso de Medicina, 79,1\% dos alunos pertencem à classe alta, $80,3 \%$ no curso de Engenharia, $72,7 \%$ no curso de Arquitctura, $68,1 \%$ no curso de Direito, enquanto que o total de alunos com pais de ocupaçōes semi ou nâo especializadas é de apenas 1,6\%. Mais alarmante do que estes dados säo as prospecçōes fcilas por Mauro, em seu trabalho "Influência de condiçōes sócio-econômicas no acesso d̀ Universidade brasileira" (1985). Analisando os relatorios dos concursos vestibulares de 1979 a 1984 realizados pela FUVEST e CESGRANRIO, o autor fez as projeções para 1990, em funçäo das tendências observadas no perfodo, e concluiu: "que, fatalmente, se elevará o fndice de clitização da universidade pública:

- a maioria dos candidatos será oriunda das escolas de $2^{2}$ grau particulares $\mathrm{cm}$ percentuais muito mais significativos de que aqueles registrados $\mathrm{cm} 1979$, como mostra o grálico n 2 ;

\section{GRAFICO 2}

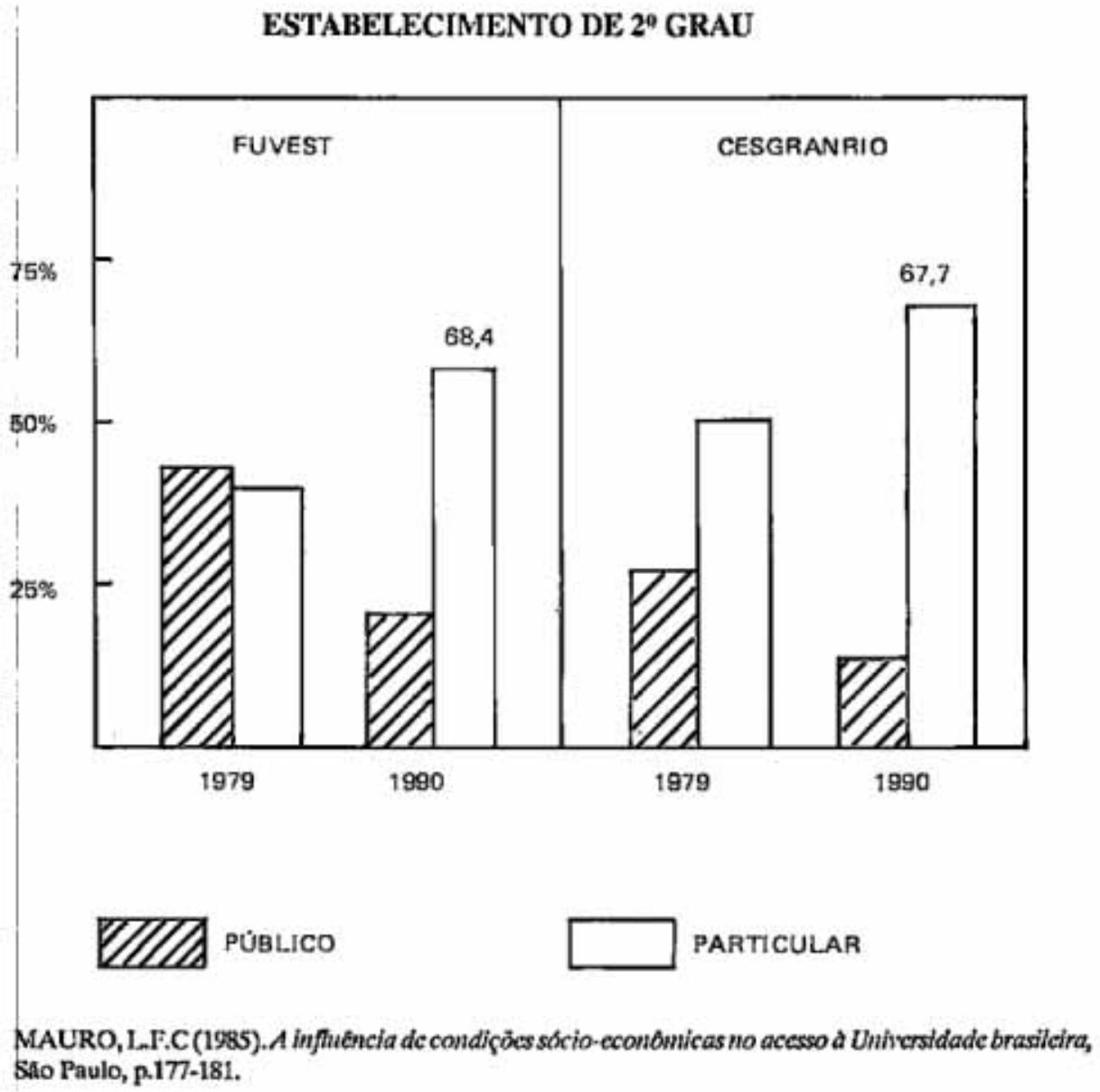


- o nível de escolarizaçáo dos pais dos candidatos, em 1990, superará expressivamente o dos classificados em 1979, conforme se observa nos gráficos $n^{\circ} 3$ e n⿳亠口冋;

GRAFICO 3

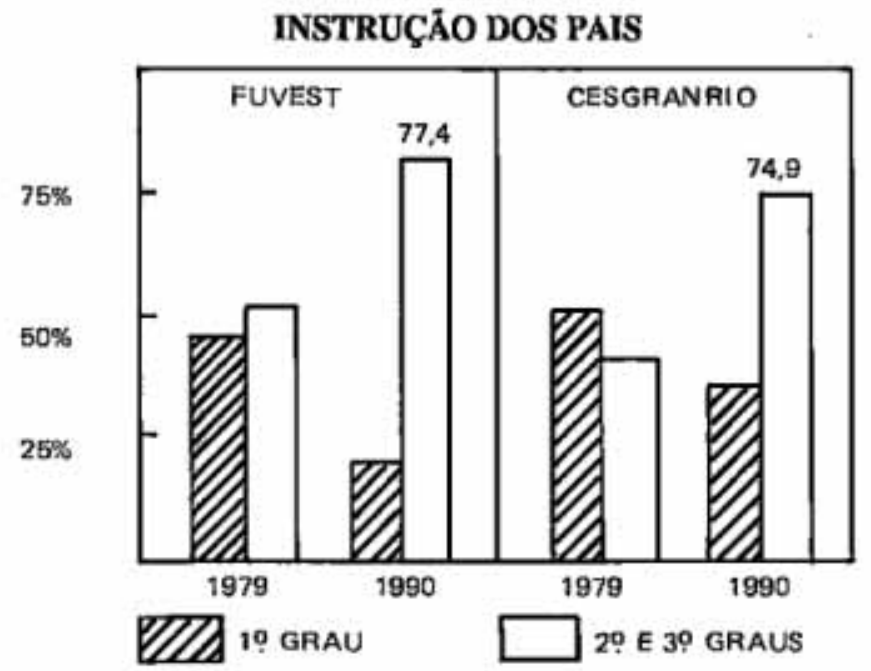

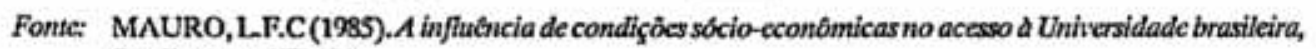
Săo Paulo, p.177-181.

GRAFICO 4

INSTRUÇÃO DAS MÃES

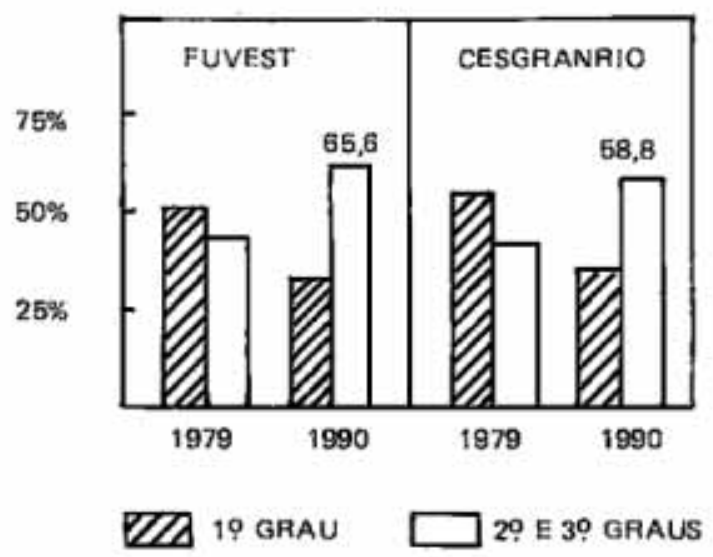

Fonte: MAURO, L.F.C(1985). A infuência de condiçöes sócio-econOmicas no acesso d Unhivenidade brastleira, Såo Paulo, p.177-181. 
- os pais de candidatos deverão pertencer, na sua maioria, à mais alta faixa ocupacional, tais como alto funcionário público, alto funcionário de empresas privada, profissional liberal, banqueiro, fazendeiro, industrial, grande acionista (gráfico n5);

\section{GRÁFICO 5}

\section{FAIXA OCUPACIONAL DOS PAIS}

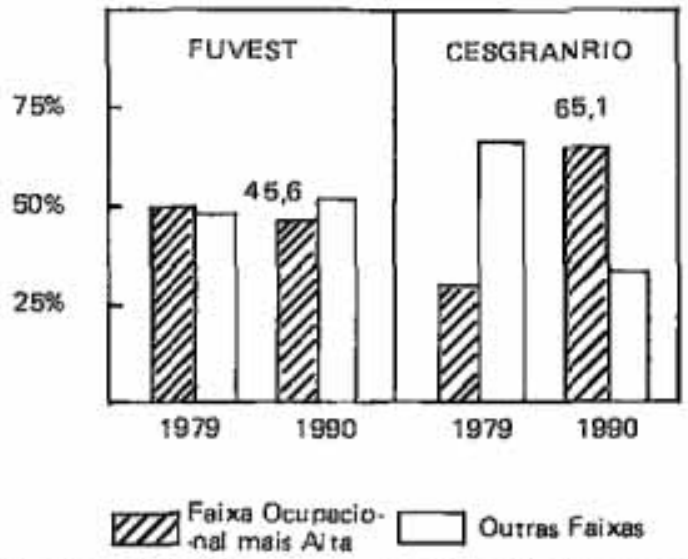

Fonte: MAURO, L.F.C.(1985). A infuetncia de condïgỏes socio-econômicasno acesso d Universidade brasileira, \$lo Paulo, p.177-181.

- a renda familiar de mais de um terço dos candidatos deverá ser superior a dez salários mínimos, como mostra o gráfico $\mathrm{n}^{\circ} 6^{n}$.

GRÁFICO 6

\section{RENDA FAMILIAR}

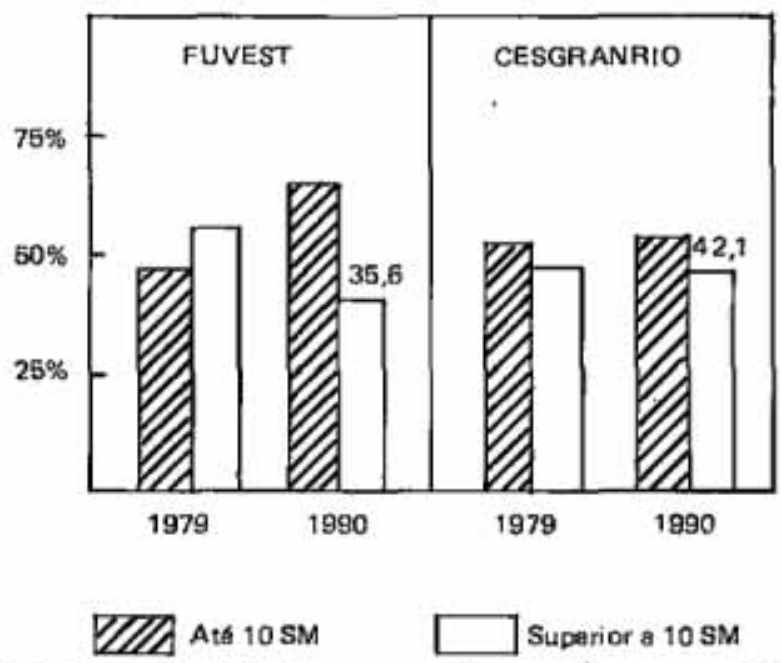

Fonte: MAURO, L.F.C(1985). A huffutencia de condiçcēes socio-economicas no acesso d Universidade brasilcina, Sáo Paulo, p.177-181. 
c) falta de preparo intelectual da grande maioria dos alunos que procuram $03^{\ell}$ grau de cnsino, fruto de uma formaçäo fundamental e secundária deficientes oferecida pelas escolas póblicas, onde professores mal remunerados e sem preparo juntam-se auma carência de laboratórios e bibliotecas para proporcionar um ensino cab́tico e de má qualidade. Além do mais, um precário domf́nio do conteúdo das matérias ensinadas por boa parte do corpo docente do $1^{2} \mathrm{e} 2^{\circ}$ graus vem proporcionando um ensino superficial e de baixo nfvel, que tem levado o alunado a exprimir-se com dificuldade, a organizar mal suas idéias $\mathrm{e}$ a năo estabelecer relaçōes na interpretaçăo de fatos. Nada mais logico, portanto, que os alunos das escolas particulares, onde pratica-se um ensino de melhor qualidade, levem uma nftida vantagem sobre aqueles que vêm dos estabelecimentos oficiais;

d) falta de alternativas para o exerć́cio de uma profissão após a conclusão do $2^{\circ}$ grau, uma vez que este nf́vel de ensino manteve o seu caráter geral, sem uma terminalidade que ofereça uma capacitaçăo lócnica que permita o ingresso no mercado de trabalho. Por outro lado, a sociedade brasileira sempre manteve uma aspiraçio mítica em relaçăo aos privilégios proporcionados pelo diploma universitário, o que resulta numa forte pressâo em busca de um lugar na Universidade, mesmo que seja em cursos marginais ou para os quais năo se tenha pendor. Tal fato vem produzindo índices alarmantes de desistência de cursos, longa permanência para a integralizaçäo dos currículos, grandes solicitaçöes para a mudança de carreiras e até o puro e simples abandorio de diplomas obtidos;

e) alunos ricos no ensino público têm sido uma das graves distorçöes do ensino superior brasileiro, o que foi mostrado largamente nos relatos apresentados neste trabalho. Este fato, com as tendencias apontados para os próximos anos, cria uma expectativa indesejável de elitizaçäo crescente da Universidade, especialmente nas instituiçōes públicas. Dentro desta moldura de elevada demanda por cursos de nfvel superior, agravada pela limitação de vagas oferecidas pelas instituiçōes e pelo crescimento demográfico da populaçäo brasilcira em 2,0 a 3,0\% ao ano, torna-se indispensável a adoçäo de uma sistemática de seleçäo via concurso vestibular, o que provoca, conforme vimos, cada vez mais e de forma indesejada, a escolha de candidatos de nível sócio-cconômico mais clevado para os cursos de maior prestigio, que sảo mantidos, em sua maioria, pelo sistema público de ensino. Aliás, Vianna (1987), no artigo Acesso à Universidade: un estudo de validade, reafirma isto com muita propricdade:

"O vestibular é, assim, indispensável dentro do atual sistema, que privilegia os privilegiados a fim de que possam usufruir mais um privilegio: o ensino de $3^{\circ}$ grau."

1) alunos pobres no ensino pago têm sido o resultado de sua exclusăo na procura do ensino em uma instituiçäo pública, o que também o leva a obter vaga em cursos de baixo prestígio e de má qualidade. Mauro (1985), na sua tese sobre o assunto, diz o seguinte:

"Num contexto assim configurado, cumpre reconhecer que a par disso, e por causa disso, a propria gratuidade do ensino público de nfvel superior, cujo objetivo, em tese, seria o de democratizar de vez os beneficios da educaçăo, passa a desempenhar, contraditbria e paradoxalmente, papel oposto. $E$ isso porque o Estado, ao garantir gratuidade 
indiscriminada e amparando com isso, precisamente, os ahunos oriundos de estratos sociais mais altos - que, afinal, säo os que chegam em maior número ao ensino superior - se mostra passivo d̀ insuperáveis dificuldades daqueles cuja situaçâo financeira é precária. O que, em última instância, importa atentar contra princlpio maior, o da Justiça Social."

\subsection{Necessidades básicas para o final do século}

Tendo em vista as expectativas para o término deste século, espera-se da educaçäo supcrior do país uma resposta aos grandes questionamentos feitos pelos diferentes segmentos da socicdade, especialmente a respeito de uma polftica clara para este nfvel de ensino.

Para o atual período governamental, o $1^{\circ}$ PND-NR estabelece o seguinte:

“A nova repíblica dïspōe-se a vencer a crise da Universidade brasileira. Para tanto, foram fixadas as seguintes diretrizes pollticas:

- restaurar e restituir à universidade brasileira suas condiçöes de pleno funcionamento para que possa cumprir com autonomia, liberdade de trabalho, competência e qualidade, sua missão cientiffica e pedagógica;

- para que isto ocorra, importa adequar a cducaçäo superior à nova realidade do pals e torna-la mais eficiente para responder as demandas da sociedade e do desenvolvimento, particulamente em termos de qualificaçdo e capacitaçẫo cientifica e tecnológica;

- esta adequaçáo passa pela soluçäo de problemas crónicos que resistem ao tempo e se agudizaram nos últimos anos, quais sejam: manutençäo das IES federais, revisão de métodos, conteudos e organizaçăo do trabalho acadêmico; desobstrução de amarras legais e normativas que inviabilizam a autonomia universitária e a estabilidade de bons programas, proporcionando flexibilidade e condiçöcs para que as universidades mesmas operen as mudanças, dentro dos padrôes de qualidade e responsabilidade pública."

Dentro de uma perspectiva para a próxima decada, podemos estabelecer que uma politica destinada ao ensino superior deverá considerar necessariamente:

a) o fortalecimento da pesquisa cientifica e tecnológica como forma de galgar degraus c queimar etapas do processo de desenvolvimento cconômico, para o qual servirá de base indispensável;

b) a formaçăo de quadros técnicos necessários ao mercado de trabalho, em quantidade e qualidade, $\mathrm{c} \mathrm{cm}$ condiçōes de responder com eficiência as demandas do desenvolvimento cconômico e tecnologico;

c) a adoçäo de novas concençōes de ensino superior pela utilização de meios cletrônicos, de cursos intensivos, de educação à distância e tutorial que, sem perda dos padrōes de qualidade e competência, poderăo atingir grandes massas de estudantes;

d) a adequaçâo dos cursos e currículos às constantes mutaçōes do mercado de trabalho, de modo a preparar um profissional polivalente, de sólida formaçäo básica nas grandes áreas do conhecimento e capaz de se adaptar com facilidade às variaçóes da demanda de empregos; 
e) o ajustamento do ensino superior à realidade do Pals de modo a permitir uma compatibilidade entre vagas oferecidas, pessoas formadas e empregos disponiveis.

\subsection{Politicas e estratégias}

Associando-se os dados referidos às expectativas mencionadas até o final do século em rclaçāo ao quadro de acesso ao ensino superior brasileiro e considerando que o crescimento econômico do pafs depende basicamente de uma oferta adequada de pessoal de nivel superior, em quantidade e em qualidade, entendemos que devam ser adotadas as seguintes politicas:

1) Expandir as vagas nas Instituiçōes de Ensino Superior, considerando a necessidade de atendimento do mercado de trabalho e do crescimento econômico do pais, sem descuidar dos critérios que produzam qualidade $\mathrm{e}$ competência do formando.

II) Democratizar o acesso ao ensino superior pelo estabelecimento de condiçōes mais equitativas de competitividade no concurso vestibular, através de um amparo cfetivo ao estudante carente.

III) Fomentar os programas de apoio aos estudantes que iniciam a Universidade como forma de diminuir as acentuadas diferenças sócio-econômicas verificadas, com o objetivo de permitir-lhe um melhor aproveitamento nos estudos superiores.

IV) Criar novos cursos profissionalizantes a nível de segundo grau de modo a introduzir modalidades alternativas de estudo e de atendimento ao mercado de trabalho.

Definidos os objetivos das politicas a adotar em relaçăo ao acesso ao ensino superior, devem ser estabelecidas as linhas de açäo mais favoráveis para alcançar os fins desejados.

Daf́a necessidade de estabelecer as estratégias para o problema, especialmente no que se refere às prioridades que scrảo escolhidas, ao uso dos recursos disponiveis e à concentração de esforços.

Para cada uma das políticas fixadas serão estabelecidas linhas de ação, que se imagina ser o melhor caminho para atingir os objetivos colimados.

Estas estratégias seräo as seguintes:

1) Para a expansäo de vagas nas IES, sem descuidar dos critérios que produzem qualidade e competencia do formando:

1. aumentar a oferta de vagas nas instituições públicas na medida das possibilidades e nas áreas de maior demanda;

2. introduzir os cursos noturnos, especialmente nas instituiçōes públicas, para atendimento dos estudantes que trabalham durante o dia, porém sem relegar os critérios de qualidade e competencia;

3. proceder uma avaliaçäo entre as vagas atualmente ofertadas, o número de conclusōes e as possibilidades de emprego em determinadas profissōes. 


\section{II) Para a democratizaçäo do acesso ao ensino superior:}

1. universalizar o ensino de primeiro e segundo graus de maneira a permitir que os egressos destes níveis adquiram conhecimentos e habilidades indispensáveis à formaçäo superior;

2. melhorar de forma substancial a formaçáo dos professores do ensino fundamental e secundário para que os mesmos possam transmitir conteúdos mais rigorosos e extensos;

3. instituir salários compativeis para os professores de ensino fundamental e secundário, como também proporcionar-Ihes condiçōes adequadas de trabalho;

4. exigir das Universidades c Estabclecimentos Isolados uma maior responsabilidade na formaçäo de professores do ensino básico, através de um apoio cfetivo à licenciaturas;

5. utilizar os recursos oriundos da cobrança da taxa de inscriçăo dos concursos vestibulares na concessāo de bolsas $\mathrm{c}$ auxilios à formação de professores de nivel primário c sccundário;

6. promover pesquisas educacionais que procurem diagnosticar com fidelidade os condicionantes s6́cio-econômicos do acesso à Universidade brasilcira.

III) Para fomentar os programas de apoio aos estudantes que iniciam a Universidade:

1. ampliar as bolsas de estudo para as instituiçốes públicas e privadas, obedecendo-se a um duplo critério de competência c carência de recursos, exigindo, no entanto, uma contra prestaçảo de serviços de natureza apropriada por parte do beneficiado;

2. rever a gratuidade do ensino público de nível superior, com o objetivo de cobrar dos alunos que podem pagar, vinculando os recursos arrecadados a programas $\mathrm{cm}$ favor dos que não têm condiçōes sócio-econômicas;

3. estabelecer diversas formas de apoio ao estudante carente tais como assistência médica, dentária, alimentar, habitacional, cultural, esportiva e artística.

IV) Para criar cursos profissionalizantes a nivel de segundo grau de modo a introduzir modalidades alternativas de estudo:

1. resgatar o ensino técnico-profissionalizante como uma forma propria de educaçäo integrada do adolescente e do jovem trabalhador;

2. reorientar as modalidades especialtzadas de educaçäo profissionalizante, mediante a apropriaçäo de tecnologias avançadas, com vistas a aumentar sua eficácia social e econômica;

3. climinar os aspectos corporativistas c cartoriais do exercício profissional do Pás, que vêm limitando a liberdade das instituiçōes de ensino superior no estabelecimento de novos currículos e formatos educacionais. 